Article

\title{
Application of Large-Scale, Multi-Resolution Watershed Modeling Framework Using the Hydrologic and Water Quality System (HAWQS)
}

\author{
Haw Yen ${ }^{1, *}$, Prasad Daggupati ${ }^{2}$, Michael J. White ${ }^{3}$, Raghavan Srinivasan ${ }^{2}$, Arndt Gossel ${ }^{4}$, \\ David Wells ${ }^{5}$ and Jeffrey G. Arnold ${ }^{3}$ \\ 1 Blackland Research and Extension Center, Texas A\&M Agrilife Research, Texas A\&M University, \\ 720 East Blackland Road, Temple, TX 76502, USA \\ 2 Department of Ecosystem Science and Management, Texas A\&M University, College Station, \\ TX 77843, USA; pdaggupati@tamu.edu (P.D.); r-srinivasan@tamu.edu (R.S.) \\ 3 Grassland, Soil \& Water Research Laboratory, Agricultural Research Service, \\ U.S. Department of Agriculture (USDA-ARS), 808 East Blackland Road, Temple, TX 76502, USA; \\ mike.white@ars.usda.gov (M.J.W.); jeff.arnold@ars.usda.gov (J.G.A.) \\ 4 Oak Ridge Institute for Science and Education, c/o U.S. Environmental Protection Agency, \\ Office of Water, Washington, DC 20460, USA; gossel.arndt@epa.gov \\ 5 U.S. Environmental Protection Agency, Office of Water, Washington, DC 20460, USA; dwells@his.com \\ * Correspondence: haw.yen@gmail.com or hyen@brc.tamus.edu; Tel.: +1-254-774-6004
}

Academic Editor: Karl-Erich Lindenschmidt

Received: 11 December 2015; Accepted: 16 February 2016; Published: 21 April 2016

\begin{abstract}
In recent years, large-scale watershed modeling has been implemented broadly in the field of water resources planning and management. Complex hydrological, sediment, and nutrient processes can be simulated by sophisticated watershed simulation models for important issues such as water resources allocation, sediment transport, and pollution control. Among commonly adopted models, the Soil and Water Assessment Tool (SWAT) has been demonstrated to provide superior performance with a large amount of referencing databases. However, it is cumbersome to perform tedious initialization steps such as preparing inputs and developing a model with each changing targeted study area. In this study, the Hydrologic and Water Quality System (HAWQS) is introduced to serve as a national-scale Decision Support System (DSS) to conduct challenging watershed modeling tasks. HAWQS is a web-based DSS developed and maintained by Texas A \& M University, and supported by the U.S. Environmental Protection Agency. Three different spatial resolutions of Hydrologic Unit Code (HUC8, HUC10, and HUC12) and three temporal scales (time steps in daily/monthly/annual) are available as alternatives for general users. In addition, users can specify preferred values of model parameters instead of using the pre-defined sets. With the aid of HAWQS, users can generate a preliminarily calibrated SWAT project within a few minutes by only providing the ending HUC number of the targeted watershed and the simulation period. In the case study, HAWQS was implemented on the Illinois River Basin, USA, with graphical demonstrations and associated analytical results. Scientists and/or decision-makers can take advantage of the HAWQS framework while conducting relevant topics or policies in the future.
\end{abstract}

Keywords: decision support system; watershed modeling; web-based application; model calibration; SWAT

\section{Introduction}

In recent years, large-scale watershed modeling has been implemented broadly in the field of water resources planning and management [1,2]. Complex hydrological, sediment, and nutrient 
processes can be simulated by sophisticated watershed simulation models so that substantial issues such as pollution control, sediment transport, water resources allocation and reservoir operation can be further explored [3,4]. Modelers and decision-makers can take advantage of the scientifically credible results as a reference to conduct corresponding acts or general policies in practice [5].

Several commonly adopted models such as the Agricultural Policy/Environmental eXtender Tool (APEX [6]), Hydrological Simulation Program-Fortran (HSPF [7]), and Soil and Water Assessment Tool (SWAT [8]) are suitable for large-scale analysis. SWAT has been demonstrated to have acceptable performance in terms of model predictions by reflecting anthropogenic activities in detail [9]. SWAT is developed and maintained by the Agricultural Research Service, U.S. Department of Agriculture (USDA-ARS), for the past 30 years. More than 2000 peer-reviewed journal articles are available online for SWAT users as a reference of applications [10]. The operation of SWAT can be fairly straightforward by implementing the user-friendly ArcSWAT interface maintained by Texas A \& M University. Similar to the Geographic Information System (GIS), users can delineate the targeted watershed and incorporate essential information such as soil properties, land use type, and conservation practices through step-by-step tutorials. Details of theories and regulated format can be found in the SWAT manual [11].

The calibration/validation of SWAT prior to application is not strictly necessary [11]. However, it is rarely the case that SWAT is deployed without carrying the additional effort of calibration in practice. It is generally performed because better model performance is always more favored in terms of model predictions and referable statistical guidelines [12,13]. In addition, interactions among hydrologic, sediment and nutrient processes may not be reflected accurately by default values of model parameters. To date, model calibration/validation can be conducted by multiple optimization tools such as the Integrated Parameter Estimation and Uncertainty Analysis Tool (IPEAT [14]) and the SWAT Calibration and Uncertainty Procedures (SWAT-CUP [15]). Users are able to perform the calibration/validation process within an affordable timespan depending on the choice of optimization schemes [16].

In considering the efficient tools available to alleviate great effort (specifically the calibration/ validation procedure) during watershed modeling, it is still cumbersome to perform tedious initialization steps such as preparing inputs and developing a model with a changing targeted study area. Therefore, a Decision Support System (DSS) that could incorporate input watershed information (e.g., soil data, land use, etc.) with simulation models is required to provide essential assistance [17,18]. In this study, the Hydrologic and Water Quality System (HAWQS [19]) is introduced as a national-scale DSS capable of performing challenging watershed modeling topics. HAWQS is a web-based DSS (designed for the contiguous United States with 48 states) supported by the U.S. Environmental Protection Agency (USEPA) and developed/maintained by Texas A\&M University. With the aid of HAWQS, users can generate a SWAT project (default parameters generated by HAWQS have been preliminarily calibrated) within a few minutes by only providing the ending Hydrologic Unit Code (HUC) and the simulation period (note that any watershed project initiated through ArcSWAT may require a further calibration routine to ensure the quality of the simulation performance). The SWAT project provided by HAWQS can be conducted in three different spatial resolutions (HUC8, HUC10, and HUC12) and varying temporal scales (time steps in daily/monthly/annual). In addition, users can specify preferred values of model parameters instead of using the pre-defined sets.

HAWQS has the advanced capacity of integrating watershed modeling in multiple spatial and temporal scales, but there is no research conducted using HAWQS at this time. The major goal of this study is to introduce the framework of HAWQS and the corresponding applications which include the comparisons of performance between HAWQS and ArcSWAT. In the case study, the Illinois River Watershed (IRW) is used to demonstrate the operation of HAWQS in detail. Specifically, the following objectives are defined: (i) to perform a complete setup procedure of HAWQS; (ii) to provide preliminary investigation and comparisons between modeling results of water quantity and quality generated by HAWQS and ArcSWAT; and (iii) to examine watershed output responses using multiple functionalities of HAWQS. 


\section{Framework of HAWQS and Watershed Modeling}

\subsection{SWAT Model}

The SWAT model is a processed-based, semi-distributed watershed scale simulation model developed by the USDA-ARS [20]. In SWAT, a unique concept of hydrological response units (HRUs) is implemented in which land use, soil type, and land slope are incorporated within each subbasin, respectively. Water balance, sediment and nutrient losses are calculated on the basis of HRUs and summarized for each subbasin for subsequent routing through each reach of the watershed. SWAT has been implemented on various topics such as hydrologic processes, sediment transport, nutrient/carbon discharges, bacteria, and plant growth in the field of water resources, and environmental and agricultural engineering, with a large number of available literature as references [21,22].

SWAT is developed to conduct large-scale watershed simulations with the support of corresponding information [11]. A complete SWAT project can only be formulated through the use of ArcSWAT [23]. However, it can also be potentially challenging to collect and perform the initialization procedure such as collecting field data and delineating the targeted watershed. The development of HAWQS helps to alleviate the time-consuming steps for future users. In addition, user-specified thresholds (e.g., land use, soil types during the grouping step for HRUs) and model parameters can be assigned easily through this tool. Details of HAWQS are introduced in the following sections.

\subsection{HAWQS Framework}

The operational framework of HAWQS is shown in Figure 1. The HAWQS framework can be grouped into four major categories: (i) initialization; (ii) customization; (iii) output management; and (iv) output demonstration. Since HAWQS is a web-based DSS (servers are located at Texas A\&M University), users do not need to have any computational capacity to carry through the process of delineation, simulation, or demonstration. In addition, scheduled computational work (e.g., SWAT simulations) will be continuously carried out even when the web interface is closed. Users have the option to be informed via email when the conducted runs are completed. The data used in HAWQS is briefly described as follows:

Atmosphere Deposition-National Atmospheric Deposition Program (NADP) [24] Climate-Parameter-elevation Regressions on Independent Slopes Model (PRISM) [25]

Land Use (non-agricultural)—National Land Cover Database (NLCD) [26]

Land Use (agricultural)_National Agricultural Statistics Service (NASS) [27]

Reservoirs-National Inventory of Dams (NID) [28]

River Discharge-United States Geological Survey (USGS) [29]

Soil-States Derived from the NRCS State Soil Geographic (STATSGO) [30]

Topography-United States Geological Survey (USGS) [31]

Water Usage-United States Geological Survey (USGS) [32] 


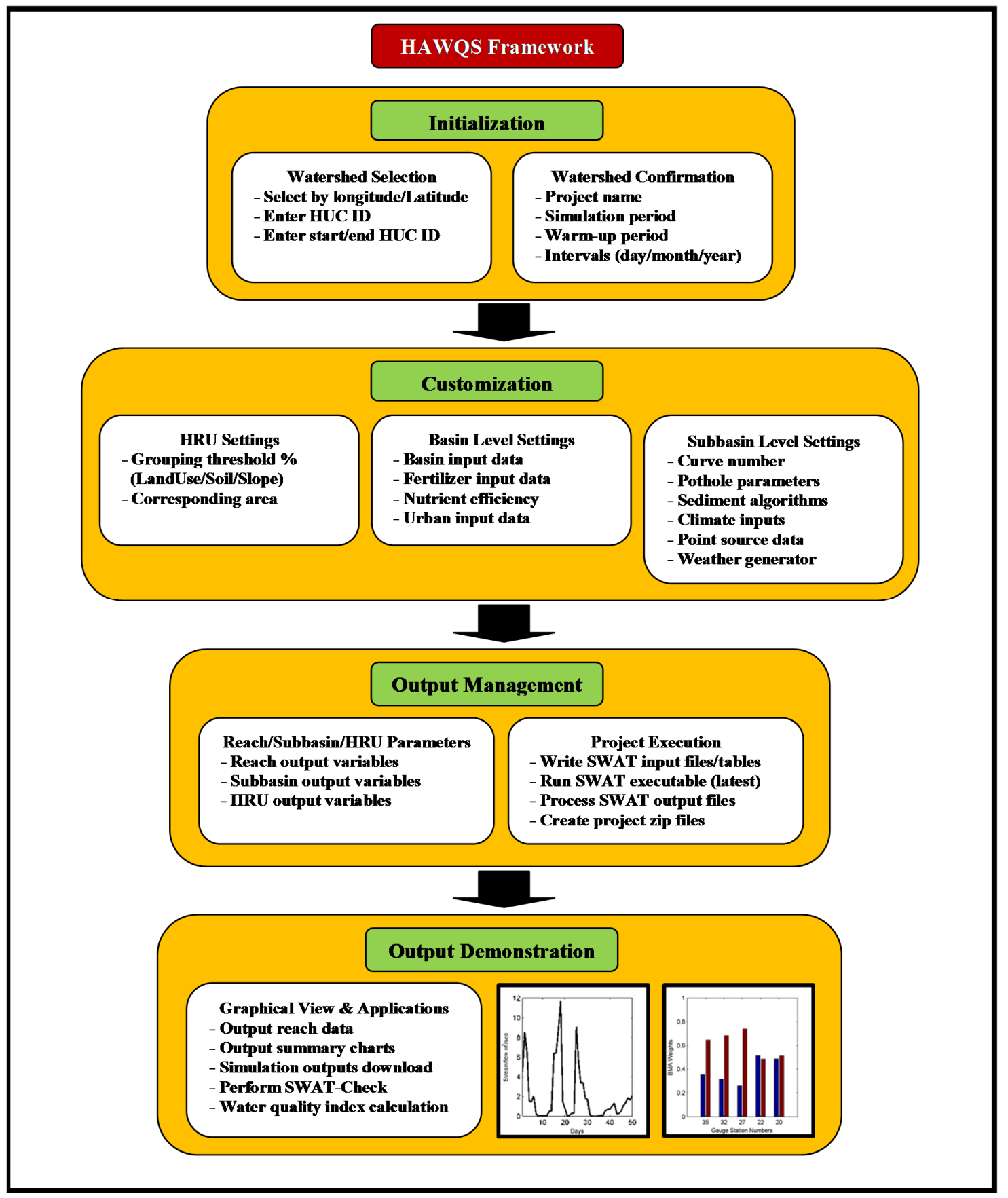

Figure 1. Organogram of the HAWQS operational framework.

\subsubsection{Initialization}

There are two major steps of the initialization stage: (i) watershed selection and (ii) watershed confirmation. As shown in Figure 2, three alternatives are available to choose (delineate) the targeted watershed. The first option is designed for beginners who are not familiar with or do not have access to specific HUC ID numbers. In this case, users can enter the projected (or estimated) latitude and longitude to find the proper HUC IDs. In the second option, users can input specific HUC IDs and also check for detail connections as confirmation. If users know the starting and ending HUC IDs exactly, the watershed will be delineated within the range accordingly. In addition, users can select the data resolution during this stage such as HUC8, HUC10, and HUC12. 


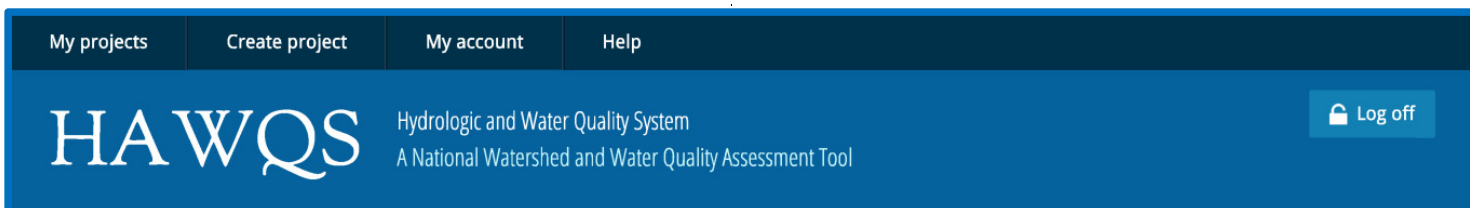

\section{Projects C Create a new project > Step 1 - Select your watershed}

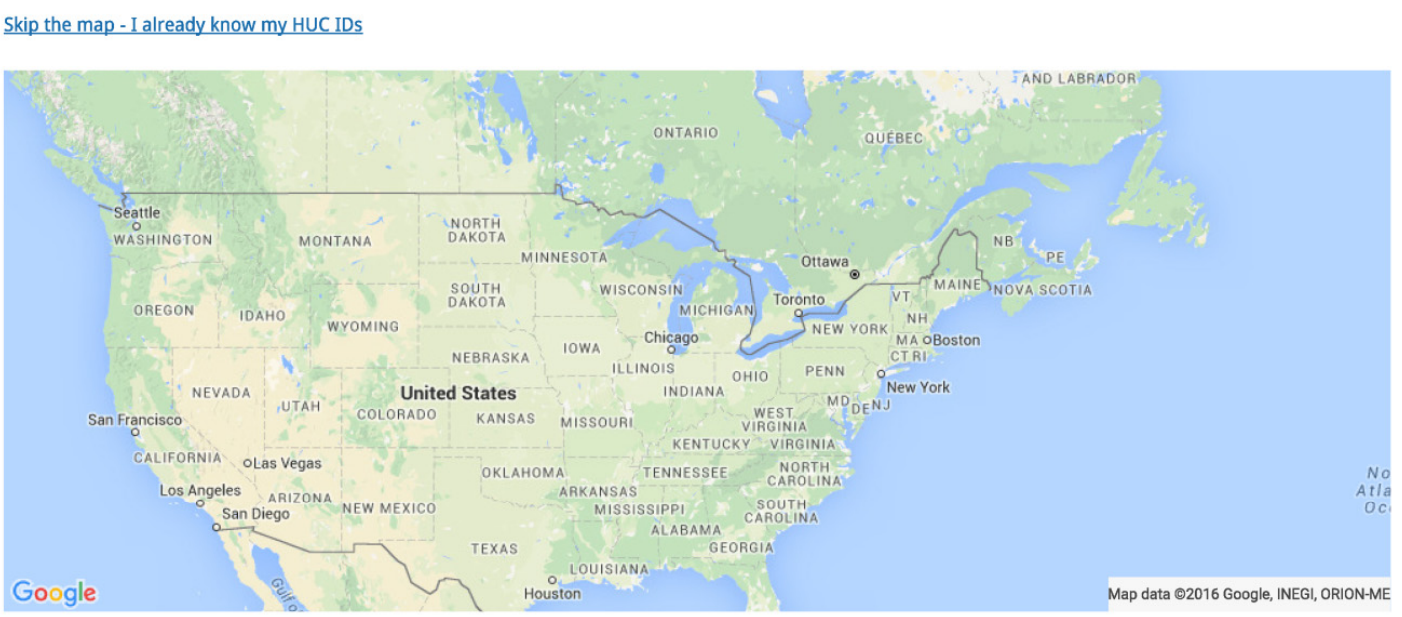

Option 1 (Easy): Click a point on the map or enter a lat/lon below to browse nearby HUC IDs.
Latitude 0 Longitude 0 Data resolution HUC 8 -

Options 2 and 3 below are intended for advanced users who are able to enter a HUC ID directly. If you are unfamiliar with HUC IDs, please use the map above.

Option 2 (Advanced): Enter a HUC ID to see connections or browse composing HUC 10/12 IDs

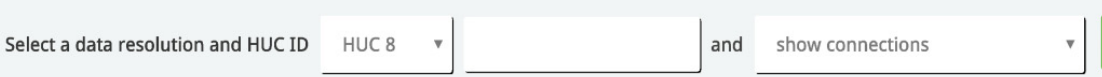

Option 3 (Advanced): Enter an ending HUC ID (8, 10, or 12-digit). You may also enter a starting HUC ID, though we recommend leaving this blank unless you plan to provide inlet data.

Figure 2. Initialization-watershed selection.

After the watershed is selected and delineated, users can specify some essential information such as the project name, simulation start/end date, number of warm-up years, printout time steps, and email notifications, which are required for the following simulation process. As shown in Figure 3, the recommended simulation dates are provided in the comments. The total length of the recommended simulation dates is based upon the available weather data such as precipitation and temperature. However, users can still change/add it later if more data is available. 


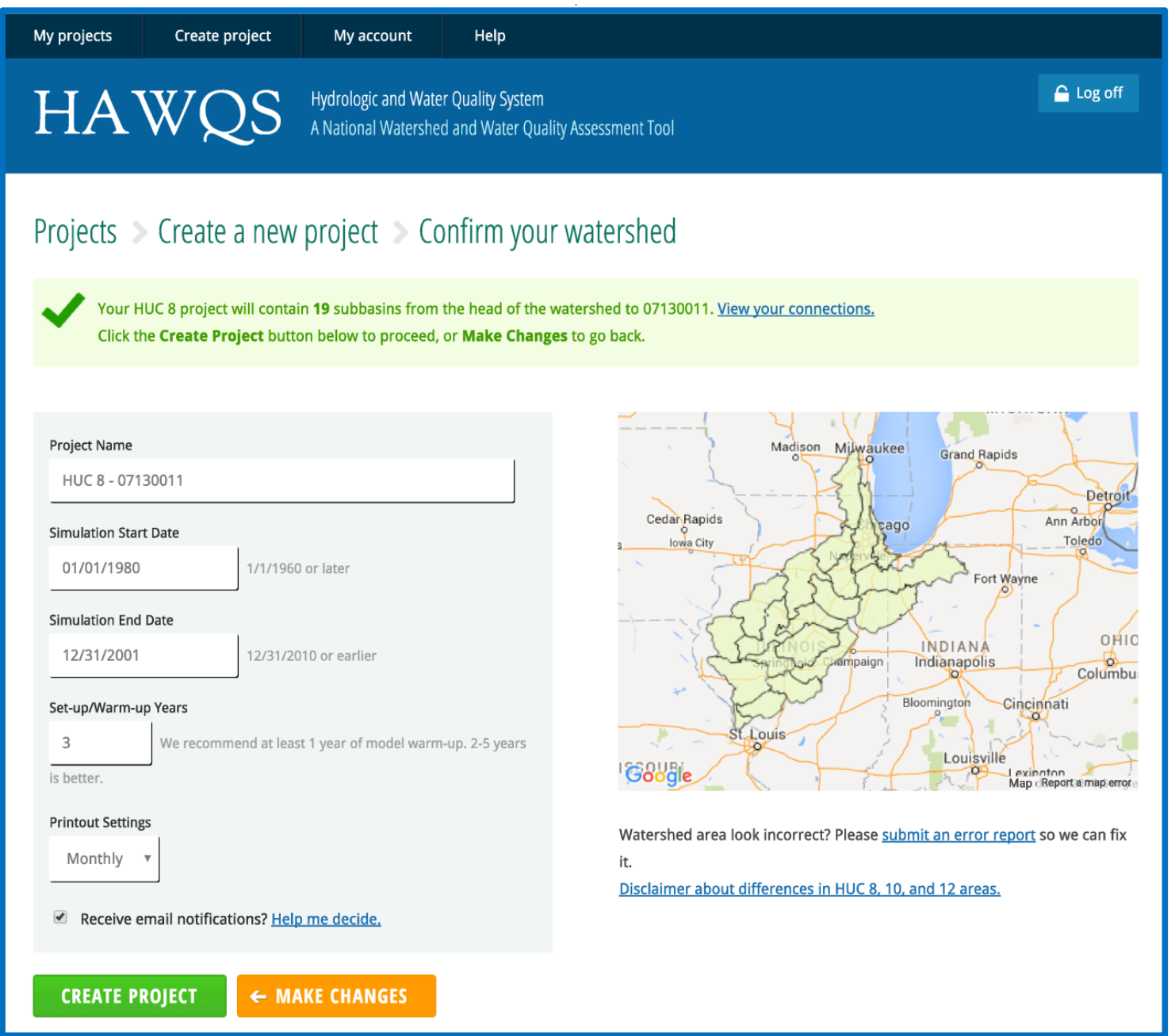

Figure 3. Initialization-watershed confirmation.

\subsubsection{Customization}

There are three major steps of the customization stage: (i) HRU settings; (ii) basin level settings; and (ii) subbasin level settings. As shown in Figure 4, users can set the grouping thresholds in percentage for the SWAT project. Land use, soil type, and slope class can be categorized based on minimum percentage values, respectively. In this case, HRUs of three different groups under the specified thresholds will be eliminated. Meanwhile, users can also select any land use that needs to be exempted from the filter.

In SWAT, model parameters can be categorized as basin and subbasin levels. For basin level parameters, the same values will be applied to the entire watershed. On the other hand, subbasin level parameters are more flexible and can be defined for each subbasin or single HRUs. As shown in Figure 4, basin level settings include basin input data, fertilizer input data, nutrient efficiency, urban input data, and land use update. Users can assign preferred values and ranges to basin level parameters for water balance (eight parameters), surface runoff (four parameters), nutrient cycling (seven parameters), and reaches (12 parameters) (see Tables A1-A4). For fertilizer input data, 54 combinations of fertilizers are available in the SWAT default. Users can update fertilizer information by changing fractions of mineral $\mathrm{N}$ (nitrate and ammonia), mineral phosphorus, organic nitrogen, and organic phosphorus through HAWQS. Users can also adjust the efficiency of fertilizer application in the following table. Similarly, 13 sets of urban input data can also be further tuned by 10 variables such as fraction of total impervious area in urban land type and curb length density in urban land type. 
Lastly, users have a decision (optional) to update land use data during a simulation run. Details and the corresponding format can be found in the SWAT manual [11].

\section{Customize SWAT Input Data}

\section{$\underline{\text { Set HRUs }}$}

Edit general watershed inputs and databases

- Basin input data

- Fertilizer input data

- Nutrient efficiency

- Urban input data

- Land use update

\section{Edit subbasin inputs}

- Curve number

- Pothole parameters

- Sediment routing method

- Climate change/sensitivity input

- Point source

- Weather generator

Figure 4. Customization: (i) HRU settings; (ii) basin level settings; and (iii) subbasin level settings.

For subbasin level inputs, users can specify parameter values (e.g., curve number, pothole parameters) or relevant inputs (e.g., sediment routing methods, climate inputs, point sources, and weather generator) in subbasin or HRU levels. For example, the curve number can be adjusted by a percentage increase/decrease to all or selected HRUs. Pothole parameters shown in Table B1 can be reassigned as preferred values from users. Five alternative sediment routing algorithms are available including the simplified Bagnold's Equation, Bagnold's Equation with modifications by each particle size, the Kodoatie model, the Molinas and Wu model, and Yang's sand and gravel model. Climate inputs and weather generators such as precipitation, temperature, and solar radiation can be further adjusted by percentage for each subbasin and also by specified months. For point source inputs, users can choose to add daily, monthly, yearly, or a constant quantity for pollutants such as nitrate, nitrite, mineral phosphorus and bacteria.

\subsubsection{Output Management}

In SWAT, simulation outputs can optionally be printed and are saved by changing the settings in the "file.cio" file. HAWQS also provides users with selected outputs to be exported and demonstrated later. As shown in Figure 5, users have optional simulation results for reach output variables (20 in maximum, Table C1), subbasin output variables (15 in maximum, Table C2), and HRU output 
variables (20 in maximum, Table C3). In addition, users can select specified HRUs (20 in maximum) for output printing.

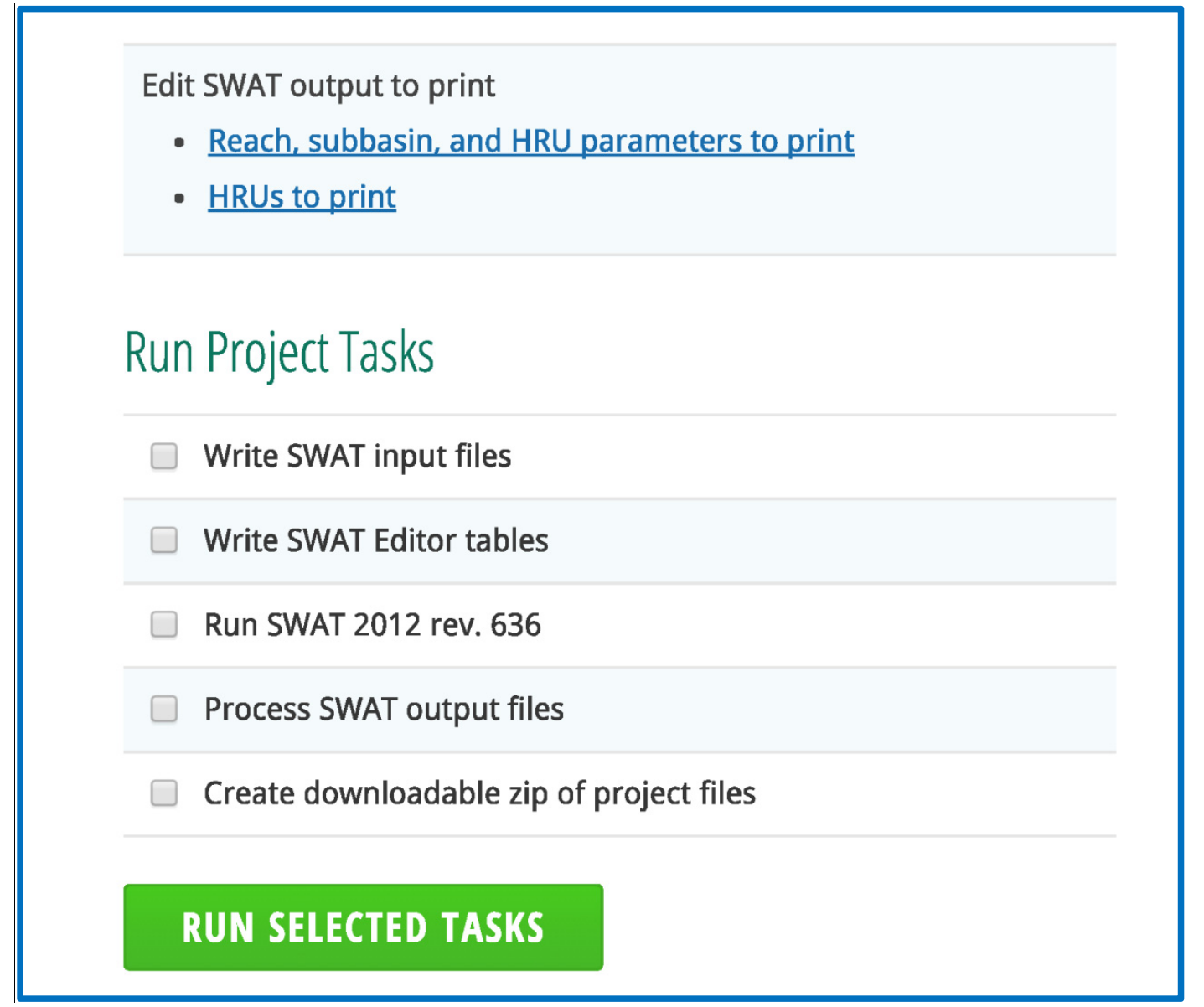

Figure 5. Output management: (i) reach/subbasin/HRU parameters; (ii) HRU output variables; and (iii) execution of the SWAT project.

To perform model runs, five tasks are available for SWAT simulations (see Figure 5): (i) write SWAT input files; (ii) write SWAT editor tables; (iii) run SWAT 2012 rec. 636 (or the latest SWAT revision); (iv) process SWAT output files; and (v) create downloadable zip of project files. Users can take advantage of these steps as a part of the operating procedure (e.g., manual calibration) by changing parameter values to obtain better-calibrated results. In addition, the conducted SWAT project will be saved as a zip file so that users can use it for the following work with minimum effort.

\subsubsection{Output Demonstration}

After the SWAT project is conducted (see Figure 6), users have options to check error statistics for the corresponding reaches and summary chart for major model responses (e.g., surface runoff, lateral flow, and groundwater). In addition, the post-processing program (SWAT-Check, [33]) and the water quality index [34] are linked with HAWQS to provide professional assessment of model outputs.

SWAT-Check was developed to conduct a stand-alone evaluation of SWAT outputs. A wide variety of model predictions can be demonstrated in graphical fashion so that users can have a better comprehension of the general performance of the model simulation. In HAWQS, it is one of the output options for users to perform SWAT-Check with one click. As shown in Figure 7, hydrological processes such as precipitation, infiltration, and ground water flow can be validated by visually assessable model outputs. 


\section{View Project Output Data}

\section{Download project files. [i] (Need help opening}

the archive?)

SWAT 2012 rev. 636 execution results

- Output reach data

- Output summary charts

- Download input.std

- Download output.std

Run SWAT Check to identify potential model problems

\section{Water quality index}

Figure 6. Output demonstration: (i) output reach data; (ii) output summary charts; (iii) download input.std and output.std files; (iv) perform SWAT-Check; and (v) water quality index calculation.

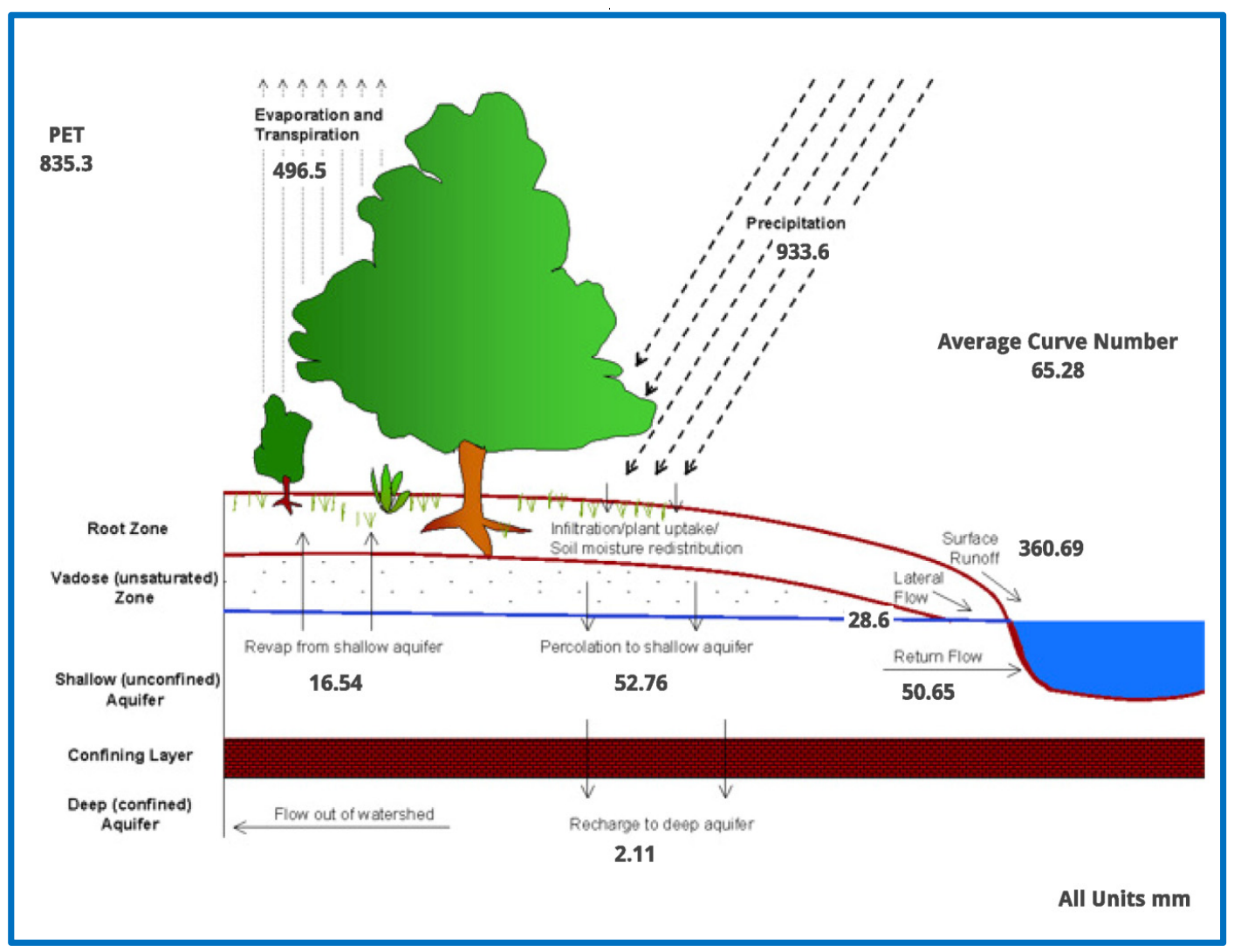

Figure 7. Hydrological outputs (process-based diagram) generated by SWAT-Check (diagrams for sediment and nutrient processes are also available in SWAT-Check [2]. 
HAWQS provides a Water Quality Index (WQI) which is a composite indicator that combines information from user-defined measurement thresholds from eight water quality parameters into a single overall value (on a 0-to-100 scale). The eight water quality parameters and their measurement thresholds are shown in Figure 8. If no user-defined thresholds are provided, the HAWQS uses the default threshold as recommended by USEPA. The Water Quality Index (0-100) is further used to assign the water bodies as highly impaired (WQI: 0-24.9), boatable (WQI: 25-49.9), fishable (WQI: 50-69.9), swimmable (WQI: 70-94.9), or safe for drinking (WQI: 95+), and associated tabular and spatial information is provided as an output summary. Such information provides guidance for states and tribes to use in adopting water quality standards. It further assists in protecting aquatic life as well as human health.

\begin{tabular}{|c|c|c|c|c|}
\hline \multicolumn{2}{|c|}{ Annual Average Water Quality Variables } & \multirow{2}{*}{$\begin{array}{l}\text { Units } \\
\text { cfu/100 mL }\end{array}$} & \multirow{2}{*}{ Valid Range } & \multirow{2}{*}{$\begin{array}{l}\text { Default } \\
126\end{array}$} \\
\hline Fecal Coliform & 126 & & & \\
\hline Biochemical Oxygen Demand, 5-day & 2.54 & $\mathrm{mg} / \mathrm{L}$ & & 2.54 \\
\hline \multicolumn{5}{|l|}{ Weights of Each of the Variables } \\
\hline Dissolved Oxygen Weight & 0.24 & & 0 to 1 & 0.24 \\
\hline Fecal Coliform Weight & 0.22 & & 0 to 1 & 0.22 \\
\hline Biochemical Oxygen Weight & 0.15 & & 0 to 1 & 0.15 \\
\hline Total Nitrogen Weight & 0.14 & & 0 to 1 & 0.14 \\
\hline Total Phosphorus Weight & 0.14 & & 0 to 1 & 0.14 \\
\hline Total Suspended Solids Weight & 0.11 & & 0 to 1 & 0.11 \\
\hline CALCULATE WQI & & & & \\
\hline
\end{tabular}

Figure 8. Units and ranges of Water Quality Index (WQI) for eight water quality variables.

\section{Implementation of the HAWQS}

HAWQS was used to conduct watershed simulation on the IRW (Figure 9) at the resolution level of HUC 8. A SWAT project was initiated and evaluated for IRW by the HAWQS web interface. The operational steps and the associated analysis are as follows: 


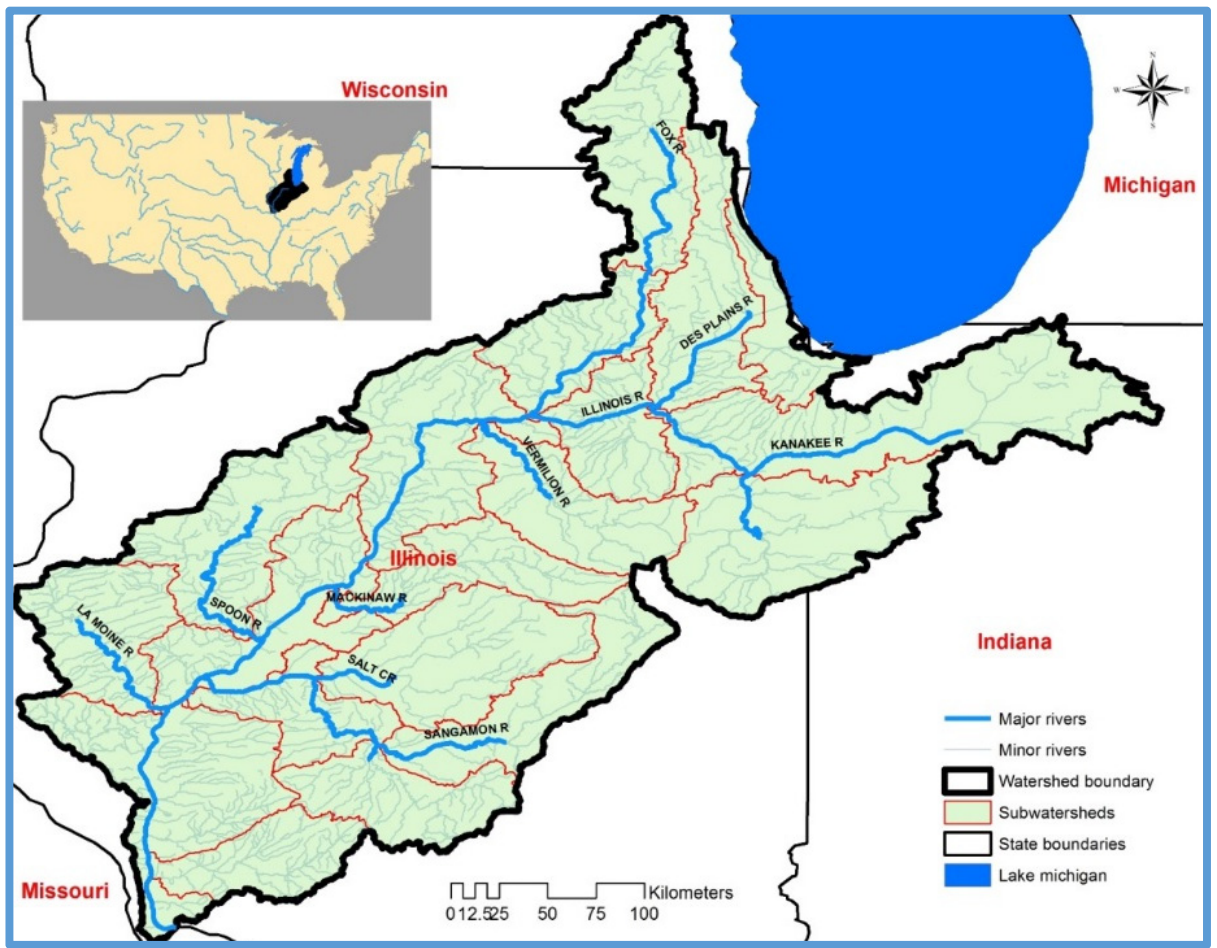

Figure 9. Location of the Illinois River Basin (IRW).

\subsection{Study Area}

IRW has a drainage area of 74,677 square kilometers and drains $44 \%$ of the state of Illinois and about 10,360 square kilometers of area in the states of Indiana and Wisconsin. The Illinois River is approximately $439 \mathrm{~km}$ in length and joins the Mississippi River near Grafton, Illinois, approximately $40 \mathrm{~km}$ northwest of St. Louis and about $30 \mathrm{~km}$ upstream from the confluence of the Missouri and Mississippi rivers. The river is one of the largest tributaries of Mississippi and connects Lake Michigan to the Mississippi River. Major branches and reaches of the IRW include Des Plaines, Kankakee, Iroquois Fox, Vermilion, Mackinaw, Spoon, Sangamon, and La Moine in the states of Illinois, Indiana and Wisconsin. Sedimentation and water quality are major issues in the IRW. As a result, the IRW has become a focus for state and federal agencies and other organizations interested in practices of integrated water management. Several best management practices (BMPs) are being discussed at watershed scale to improve sedimentation, water quality and other relevant issues [35].

\subsection{Watershed Setup with the HAWQS Interface}

\subsubsection{Step 1: Initialization of the Watershed}

Upon creating an account, the HAWQS interface gives three options for watershed selection (Figure 2). Option 1 (default option) can be deployed by clicking a point on the map or entering the location of the latitude and longitude. Options 2 and 3 are for advanced users that are able to enter the HUC ID directly. In this study, Option 3 was chosen and the ending HUC 8 ID of 07130011 was entered. This resulted in creating a SWAT model project with 19 subbasins from the head watershed of 07130011 with a start date no earlier than 1960 and an end date no later than 2010.

After the watershed selection is completed, users shall conduct the watershed confirmation (Figure 3). The start and end date of the model simulation was set from the first day of 1980 until the end of 2001 (only for demonstration purposes; different time periods were used in the case study of the later sections) with three years of warm-up period. The printout setting was assigned to be in monthly time steps. 


\subsubsection{Step 2: Customization of SWAT Input Data}

In Step 2, options are available to set HRU thresholds, edit general watershed inputs and databases, edit subbasin inputs, and edit SWAT outputs for printing (Figure 4). In this study, HRU thresholds were set to $4 \%$ each for land use, soil and slope categories to eliminate minor land uses, soils, and slopes in each subbasin. This resulted in a significant reduction of HRUs from 4856 to 707 . As mentioned previously, users can assign preferred parameter values at HRU, subbasin, and basin levels, respectively. In addition, it was also noted that the HAWQS is capable of providing preliminarily calibrated parameters (as the default) in advance. Therefore, none of the other inputs in terms of the SWAT model parameters were changed in this project.

\subsubsection{Step 3: Run SWAT Project Tasks}

In Step 3, options are available for writing SWAT input files, writing SWAT editor tables, running SWAT 2012 (revision 636), processing SWAT output files, and creating a downloadable zip of project files (Figure 5). In this study, we chose to write SWAT input files, enable SWAT editor tables, run SWAT executable, process SWAT output files, and a create a downloadable zip of project files so that it can be used externally by the SWAT editor program which can read the outputs through the interface. Step 3 is considered not only an easy way of saving/exporting initialized watershed projects, but it also can be used as an online manual calibration framework (manual calibration can be conducted by changing values of specific model parameters through the HAWQS interface) for users to derive results promptly.

\subsection{Verification of the SWAT Model}

Verification or validation is the process used to demonstrate that the model can produce realistic results in a particular application [36]. The SWAT model was executed for a period of 1980 to 2001 with three years as the warm-up period (1980 to 1982). The results produced by the SWAT model were verified using observed data. Observed data of flow, sediment and nitrogen at the United States Geological Survey (USGS) gauge station (5586100) at Valley City on the Illinois River was used to evaluate the model performance. Verification was done in two time periods to make sure the model simulations are temporally reasonable. In the case study, the first time period selected was from 1983 to 1989 and the second period was 1990 to 2001.

\subsection{Results}

\subsubsection{Results of Calibration and Validation}

In order to demonstrate the improvement in terms of model performance between HAWQS and ArcSWAT, another IRW project was conducted by ArcSWAT. Table 1 shows summary statistics of the Nash-Sutcliffe Efficiency coefficient (NSE (Equation (1) [13,37]) and Percent Bias (PBIAS (Equation (2) [12,13]) for monthly flow, sediment and total nitrogen (TN) for calibration and validation time periods. In both questions, $y_{i}^{\text {Obs }}$ is the observed data at time step $i ; y_{i}^{\text {Sim }}$ is the simulated model output at time step $i$; $y_{i}^{\text {Mean }}$ is the average observed data at time step $i ; N$ is the total time span. As shown in Table 2, the General Performance Ratings (GPR) were implemented as the quantitative criteria recommended by Moriasi et al. [12] and the monthly time step was used to evaluate the model performance.

$$
\begin{gathered}
N S E=1-\frac{\sum_{i=1}^{N}\left(y_{i}^{\text {Obs }}-y_{i}^{\text {Sim }}\right)^{2}}{\sum_{i=1}^{N}\left(y_{i}^{\text {Obs }}-y_{i}^{\text {Mean }}\right)^{2}} \\
\text { PBIAS }=\frac{100 \sum_{i=1}^{N}\left(y_{i}^{\text {Obs }}-y_{i}^{\text {Sim }}\right)}{\sum_{i=1}^{N}\left(y_{i}^{\text {Obs }}\right)}
\end{gathered}
$$


Table 1. Error statistics for monthly flow, sediment and total nitrogen (TN) for calibration (1983-1989) and validation (1990-2001) periods.

\begin{tabular}{ccccccccc}
\hline \multirow{2}{*}{$\begin{array}{c}\text { Output } \\
\text { Variables }\end{array}$} & \multicolumn{3}{c}{ IRW (HAWQS) } & \multicolumn{3}{c}{ IRW (ArcSWAT) } \\
\cline { 2 - 8 } & \multicolumn{2}{c}{ Calibration } & \multicolumn{2}{c}{ Validation } & \multicolumn{2}{c}{ Calibration } & \multicolumn{2}{c}{ Validation } \\
\cline { 2 - 8 } & NSE & PBIAS (\%) & NSE & PBIAS (\%) & NSE & PBIAS (\%) & NSE & PBIAS (\%) \\
\hline Flow & 0.70 & 8.51 & 0.72 & 13.91 & 0.61 & 7.86 & 0.49 & 21.1 \\
Sediment & 0.66 & 26.55 & 0.67 & 19.07 & -0.05 & 61.56 & -0.14 & 57.86 \\
Total Nitrogen & 0.36 & -4.15 & 0.23 & 26.78 & 0.26 & 45.14 & -0.22 & 68.54 \\
\hline
\end{tabular}

NSE: Nash Sutcliffe Efficiency coefficient; PBIAS: Percent bias; IRW: Illinois River Basin.

Table 2. Quantitative criteria categorized by the General Performance Ratings [12].

\begin{tabular}{ccccc}
\hline \multirow{2}{*}{ Performance Rating } & \multirow{2}{*}{ NSE } & \multicolumn{3}{c}{ PBIAS (\%) } \\
\cline { 2 - 4 } & & Streamflow & Sediment & Nitrogen \\
\hline Very Good & $0.75<$ NSE $\leqslant 1.00$ & PBIAS $< \pm 10$ & PBIAS $< \pm 15$ & PBIAS $< \pm 25$ \\
Good & $0.65<$ NSE $\leqslant 0.75$ & $\pm 10 \leqslant$ PBIAS $< \pm 15$ & $\pm 15 \leqslant$ PBIAS $< \pm 30$ & $\pm 25 \leqslant$ PBIAS $< \pm 40$ \\
Satisfactory & $0.50<$ NSE $\leqslant 0.65$ & $\pm 15 \leqslant$ PBIAS $< \pm 25$ & $\pm 30 \leqslant$ PBIAS $< \pm 55$ & $\pm 40 \leqslant$ PBIAS $< \pm 70$ \\
Unsatisfactory & NSE $\leqslant 0.50$ & PBIAS $\geqslant \pm 25$ & PBIAS $\geqslant \pm 55$ & PBIAS $\geqslant \pm 70$ \\
\hline
\end{tabular}

NSE: Nash-Sutcliffe efficiency coefficient; PBIAS: Percent bias.

In the first time period (1983-1989), the model performance by HAWQS was considered good for flow and sediment and unsatisfactory for TN as per NSE criteria. As per PBIAS criteria, the model performance was considered "Very Good" (also see Table 1) for flow and TN and good for sediment. In the second time period (1990-2001) period, the model performance was considered good for flow, sediment and unsatisfactory for TN as per NSE criteria. The model performance was good for flow, sediment and TN based on PBIAS criteria. On the other hand, results generated by ArcSWAT are considerably worse than HAWQS. Flow simulation ("Satisfactory") in the calibration period is the only output variable that had a performance better than unsatisfactory. Predictions for sediment and total nitrogen are evidently far away from acceptable (NSE values are mostly negative with fairly high PBIAS compared to the results from HAWQS).

The time series comparisons between observed and predicted flow, sediment and TN for the calibration and validation periods are shown in Figure 10. Comparisons of temporal processes show that the model predictions of HAWQS were in close agreement with the observed data. In addition, it is clear that temporal processes generated by ArcSWAT are apparently off the major trend and typically underestimated. It was mentioned previously that further calibration using auto-calibration tools (e.g., IPEAT, SWAT-CUP) after downloading the SWAT model from the HAWQS interface (or ArcSWAT) will improve the statistics as well as agreements of temporal time series. However, one of the major advantages of HAWQS is identifying the targeted area and providing supplementary information (e.g., model predictions of flow, sediment, and total nitrogen) within fairly short periods of time which cannot be done by ArcSWAT. The availability of general functions between HAWQS and ArcSWAT are compared in Table 3. Demonstrated limitations of ArcSWAT indicated that the dominant improvements by HAWQS over ArcSWAT have shown great advantages not only in timely matters (e.g., urgent requests need immediate solutions) but also in general applications. 


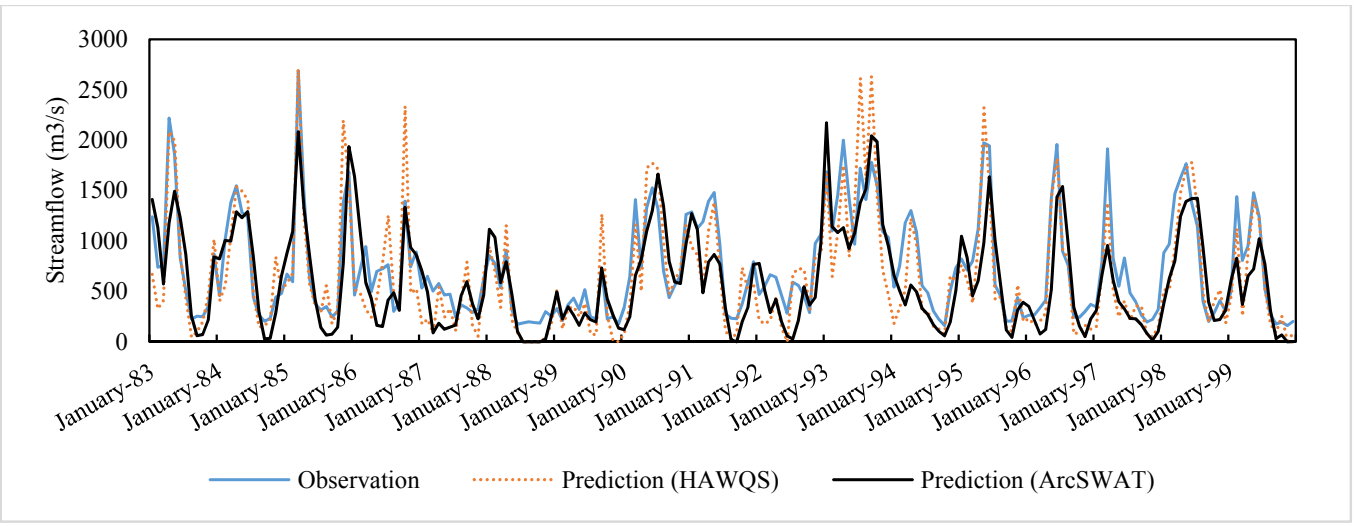

(a)

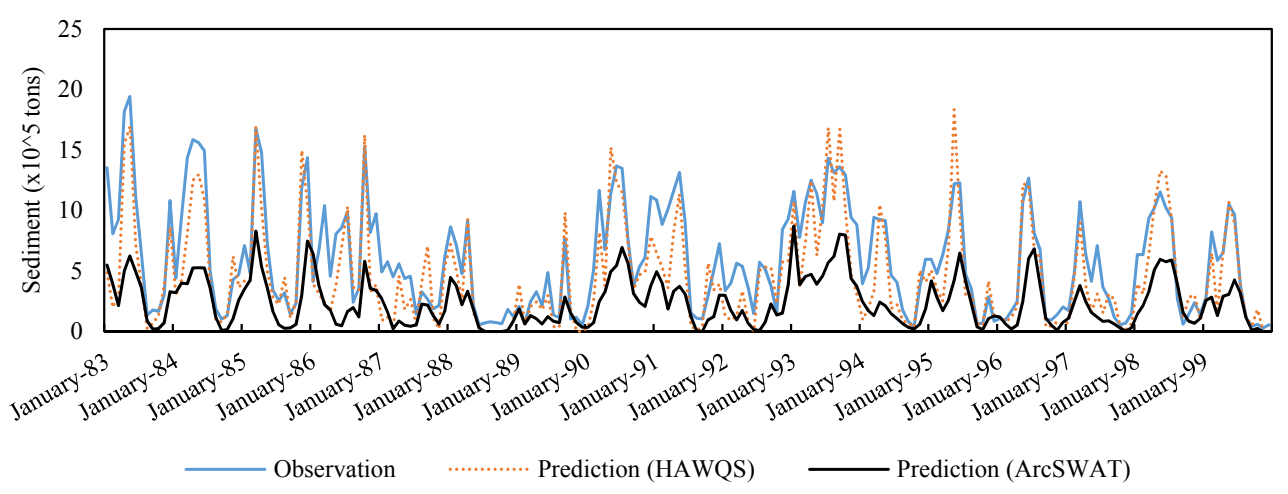

(b)

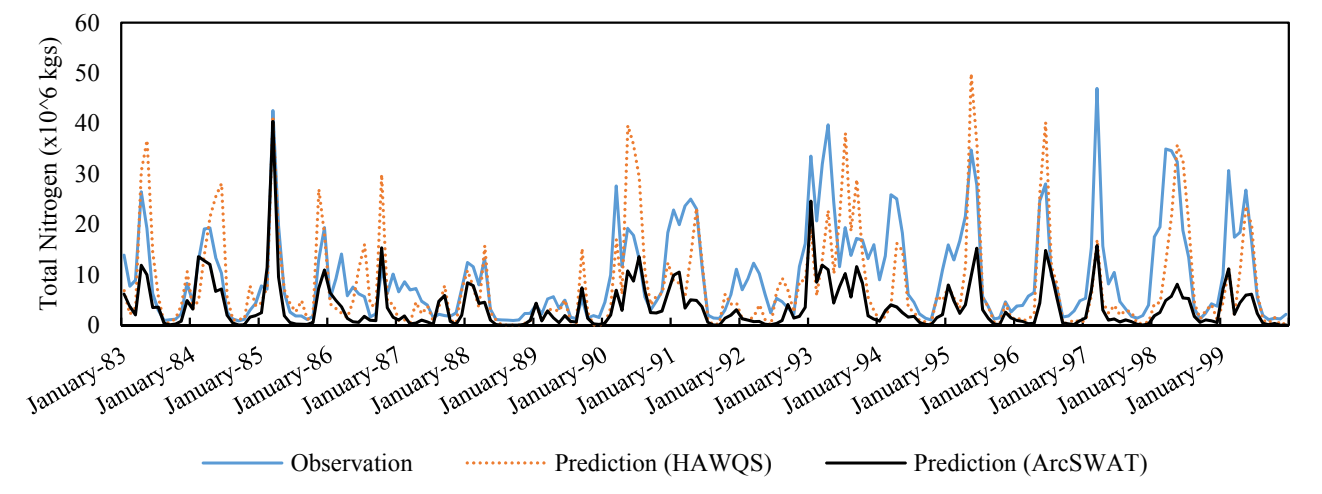

(c)

Figure 10. Time series comparisons between observed and predicted flow, sediment and TN for calibration and validation periods for the Illinois River Basin. (a) Streamflow; (b) Sediment; (c) Total Nitrogen.

Table 3. General comparisons between HAWQS and ArcSWAT.

\begin{tabular}{lcc}
\hline \multicolumn{1}{c}{ Comparisons } & HAWQS & ArcSWAT \\
\hline Graphical Demonstration & Available & Not Available \\
Available to assign preferred parameter values & Available & Not Available \\
Available for remote simulation & Available & Not Available \\
Data Collection & No Need & Required \\
Calibration requirement & No Need & Required \\
Required Software & No Need & ArcSWAT \\
Required Hardware & Regular Desktop & Regular Desktop \\
Spatial resolution & 3 Options & Not Available \\
Operation time & Few Minutes & Hours at Minimum \\
\hline
\end{tabular}




\subsubsection{HAWQS Summary Charts}

The SWAT model conducted by the HAWQS web interface was re-run, and it produced three summary charts using the data from 1983 to 2001 . The first chart is the average monthly basin values for snowfall, surface runoff, lateral flow and water yield for each month (Figure 11). The month of May produced the highest water yield and surface runoff while the month of August produced the lowest water yield and surface runoff. Snowfall is also a major contributor in this watershed, especially in the months of December to April. The second chart shows the average monthly sediment yield for each month (Figure 12). Similar to flow, the month of May produced the highest sediment yield while the month of August produced the least. The third chart shows the average annual basin values which are the components of the hydrologic budget in the watershed (Figure 13). Figure 13 helps users understand various hydrological components in the watershed. For example, the ratios of streamflow and evapotranspiration to precipitation in this watershed are 0.47 and 0.53 , respectively. In addition, the contributions of baseflow and surface runoff in this watershed are $18 \%$ and $82 \%$.

The spatial average annual WQI in the IRW is shown in Figure 14. The WQI ranged from 20 to 28 where 12 HUC 8 watersheds are boatable and six HUC 8 watersheds are highly impaired. Highly impaired watersheds are generally distributed on the northwestern side of the watershed where agricultural activities mostly dominate. Figure 14 shows that $69 \%$ of the stream length is boatable while $30 \%$ of the stream length is impaired. The water quality of streams in the IRW is neither swimmable nor safe for drinking according to the WQI with default measurement thresholds used in the investigated watershed.

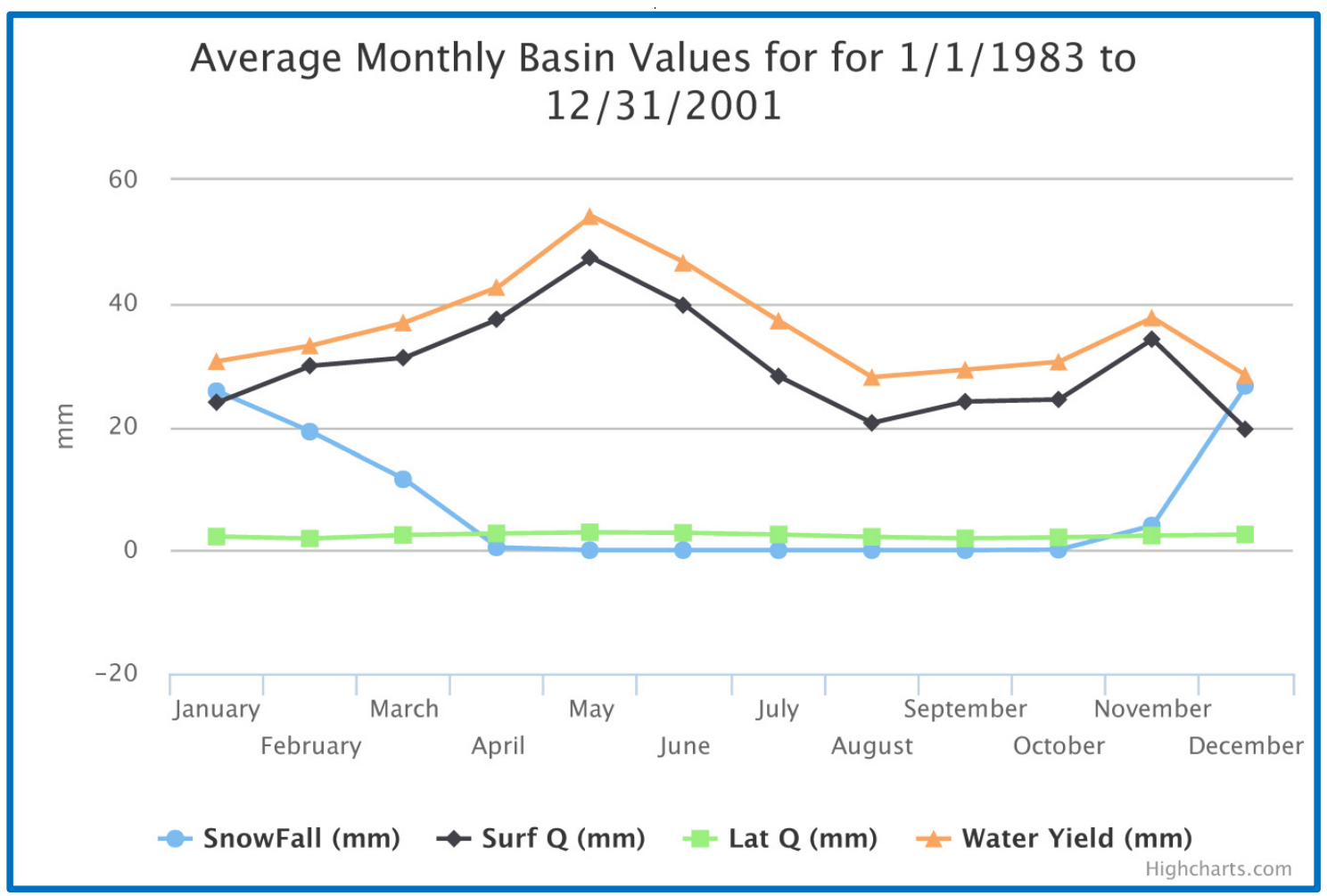

Figure 11. Average monthly basin values for snowfall, surface runoff, lateral flow and water yield for each month for the Illinois River Basin. 


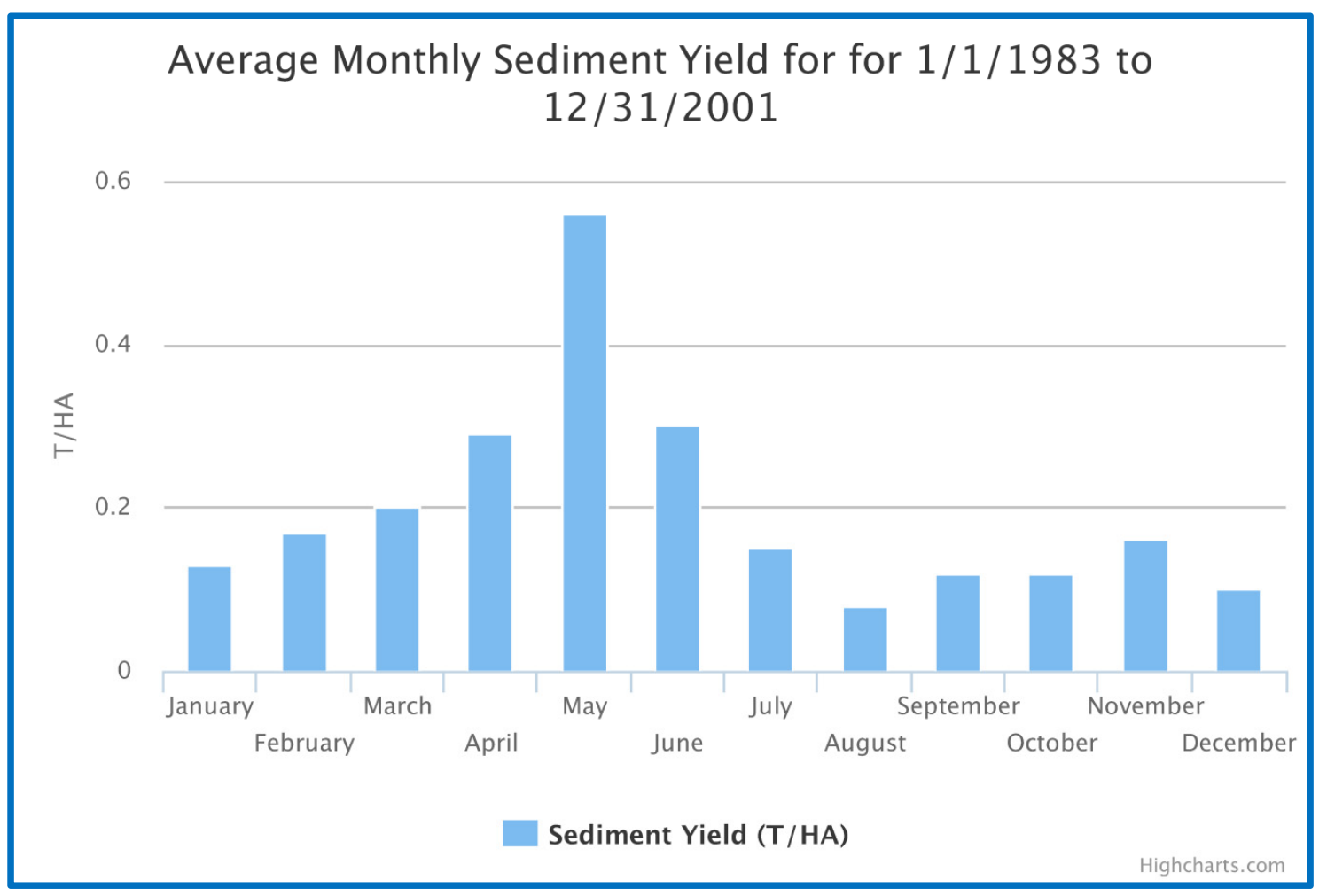

Figure 12. Average monthly sediment yield for the Illinois River Basin.

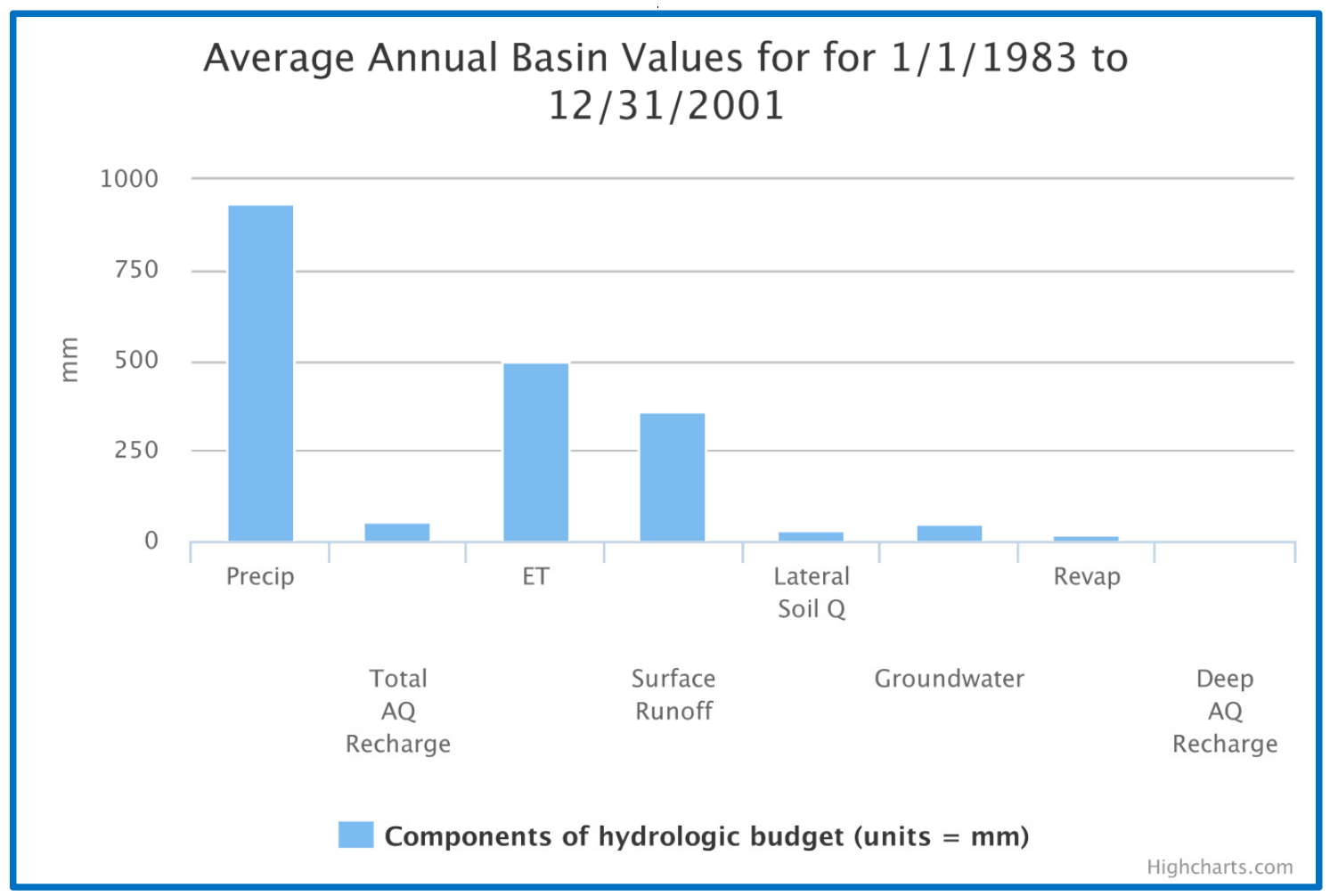

Figure 13. Average annual basin values for the hydrologic components for the Illinois River Basin. 

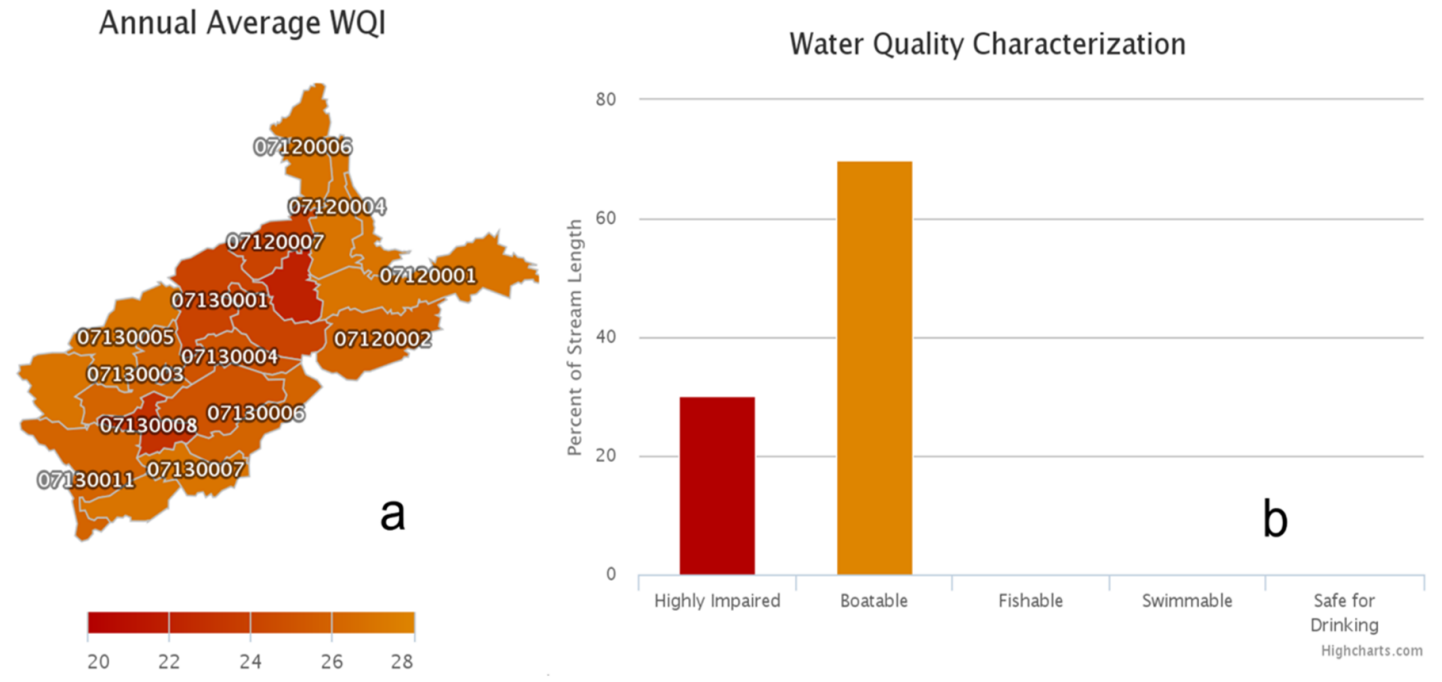

Figure 14. Water quality characterization in IRW.

\section{Conclusions}

In this study, HAWQS has been demonstrated in a step-by-step scheme on the Illinois River Basin, USA. The merit of HAWQS is not only to provide delineated watershed projects for potential users, but it can also serve as an easy-to-operate and flexible tool for the complex decision-making processes. In 2014, more than 500,000 local residents in Toledo, Ohio, were facing a drinking water crisis because of the sudden degradation of water quality [38]. With the increasing population and the associated pollution caused by anthropogenic activities, requests from decision-makers for a timely analytical report with scientific guidance could be crucial. The ordinary approach of the ArcSWAT application demonstrated in this study has shown great disadvantages in major categories. With the aid of HAWQS, users can generate a preliminarily calibrated SWAT project within a few minutes by only providing the ending of a HUC number of the targeted watershed and the associated simulation period. Scientists and decision-makers can take advantage of the propounded tool on a national scale with minimum effort and without experiencing the tedious procedure of constructing a watershed project. Therefore, more resources in terms of time and financial support can be invested in other relevant issues.

Acknowledgments: This project was funded by grants from (i) U.S. Environmental Protection Agency; and (ii) United States Department of Agriculture-Natural Resources Conservation Service (USDA-NRCS) Conservation Effects Assessment Project (CEAP) -Wildlife and Cropland components. The views expressed in this presentation are those of the authors and do not necessarily reflect the views or policies of the United States Environmental Protection Agency and the United States Department of Agriculture. USDA is an equal opportunity provider and employer.

Author Contributions and Additional Information: Haw Yen and Prasad Daggupati performed the case study (watershed modeling, simulations and analysis) and also the major writing of the manuscript. All authors are involved in the development of the HAWQS framework. The HAWQS framework is specifically developed and reserved for EPA official use only and HAWQS user interface (web interface is included) may change in future as a part of continuous updating to accommodate various needs. In addition, the Hydrologic Unit Model of the United States (HUMUS) framework which has all the functionalities of HAWQS is available and released for public use (More information is available at https:/ / humus.tamu.edu/).

Conflicts of Interest: The authors declare no conflict of interest. 


\section{Appendix A}

Table A1. Adjustable SWAT parameters for water balance functions.

\begin{tabular}{clccc}
\hline & \multicolumn{1}{c}{ Water Balance } & & \\
\hline Parameter & \multicolumn{1}{c}{ Description } & LB & UB & Default \\
\hline SFTMP & Snowfall temperature $\left({ }^{\circ} \mathrm{C}\right)$ & -5 & 5 & 1 \\
SMTMP & Snow melt base temperature $\left({ }^{\circ} \mathrm{C}\right)$ & -5 & 5 & 0.5 \\
SMFMX & Melt factor for snow on 21 June $\left(\mathrm{mm} \cdot \mathrm{H}_{2} \mathrm{O} /{ }^{\circ} \mathrm{C}\right.$-day) & 0 & 10 & 4.5 \\
SMFMN & Melt factor for snow on 21 December $\left(\mathrm{mm} \cdot \mathrm{H}_{2} \mathrm{O} /{ }^{\circ} \mathrm{C}\right.$-day) & 0 & 10 & 4.5 \\
TIMP & Snow pack temperature lag factor & 0 & 1 & 1 \\
ESCO & Soil evaporation compensation factor & 0 & 1 & 0.95 \\
EPCO & Plant uptake compensation factor & 0 & 1 & 1 \\
IPET & Potential evapotranspiration (PET) method & & \\
& [Penman-Monteith/Priestley-Taylor/Hargreaves] & & \\
\hline
\end{tabular}

Table A2. Adjustable SWAT parameters for surface runoff functions.

\begin{tabular}{ccccc}
\hline \multicolumn{1}{c}{ Surface Runoff } & & & \\
\hline Parameter & Description & LB & UB & Default \\
\hline CNCOEF & Plant ET curve number coefficient & 0.5 & 2 & 1 \\
SURLAG & Surface runoff lag time & 0.5 & 24 & 4 \\
ICN & Daily curve number calculation method [Soil moisture/Plant Evapotranspiration] \\
ICRK & Daily curve number calculation method [No model crack flow/Model crack flow in soil] \\
\hline
\end{tabular}

Table A3. Adjustable SWAT parameters for nutrient cycling functions.

\begin{tabular}{ccccc}
\hline & Nutrient Cycling & & & \\
\hline Parameter & Description & LB & UB & Default \\
\hline RCN & Concentration of nitrogen in rainfall $(\mathrm{mg} \mathrm{N} / \mathrm{L})$ & 0 & 15 & 1 \\
CDN & Denitrification exponential rate coefficient & 0 & 3 & 0 \\
SDNCO & Denitrification threshold water content & 0 & 1 & 0 \\
NPERCO & Nitrate percolation coefficient & 0 & 1 & 0.2 \\
PPERCO & Phosphorus percolation coefficient $\left(10 \mathrm{~m}^{3} / \mathrm{Mg}\right)$ & 10 & 17.5 & 10 \\
PHOSKD & Phosphorus soil partitioning coefficient $\left(\mathrm{m}^{3} / \mathrm{Mg}\right)$ & 100 & 200 & 175 \\
PSP & Phosphorus sorption coefficient & 0.01 & 0.7 & 0.4 \\
\hline
\end{tabular}

Table A4. Adjustable SWAT parameters for functions within reaches.

\begin{tabular}{|c|c|c|c|c|}
\hline \multicolumn{5}{|c|}{ Reaches } \\
\hline Parameter & Description & LB & UB & Default \\
\hline MSK_COL1 & $\begin{array}{l}\text { Calibration coefficient used to control impact of the storage time constant } \\
\text { for normal flow }\end{array}$ & 0 & 10 & 0 \\
\hline MSK_COL2 & $\begin{array}{l}\text { Calibration coefficient used to control impact of the storage time constant } \\
\text { for low flow }\end{array}$ & 0 & 10 & 3.5 \\
\hline MSK_X & $\begin{array}{l}\text { Weighting factor controlling relative importance of inflow rate and outflow } \\
\text { rate in determining water storage in reach segment }\end{array}$ & 0 & 0.3 & 0.2 \\
\hline TRANSRCH & Fraction of transmission losses from main channel that enter deep aquifer & 0 & 1 & 0 \\
\hline EVRCH & Reach evaporation adjustment factor & 0.5 & 1 & 0.4 \\
\hline PRF & Peak rate adjustment factor for sediment routing in the main channel & 0 & 2 & 1 \\
\hline SPCON & $\begin{array}{l}\text { Linear parameter for calculating the maximum amount of sediment that can } \\
\text { be reentrained during channel sediment routing }\end{array}$ & 0.00001 & 0.01 & 0.001 \\
\hline SPEXP & $\begin{array}{l}\text { Exponent parameter for calculating sediment reentrained in channel } \\
\text { sediment routing }\end{array}$ & 1 & 1.5 & 1.2 \\
\hline ADJ_PKR & $\begin{array}{l}\text { Peak rate adjustment factor for sediment routing in the subbasin (tributary } \\
\text { channels) }\end{array}$ & 0.5 & 2 & 0.5 \\
\hline IRTE & \multicolumn{4}{|c|}{$\begin{array}{l}\text { Calibration coefficient used to control impact of the storage time constant for normal flow [Variable } \\
\text { storage/Muskingum] }\end{array}$} \\
\hline IDEG & \multicolumn{4}{|c|}{ Channel degradation code [Channel dimension updated No/Yes] } \\
\hline IWQ & \multicolumn{4}{|l|}{ In-stream water quality code [In-stream nutrient and pesticide No/Yes] } \\
\hline
\end{tabular}




\section{Appendix B}

Table B1. Adjustable SWAT parameters for pothole functions.

\begin{tabular}{|c|c|c|c|c|}
\hline \multicolumn{5}{|c|}{ Pothole Parameters } \\
\hline Parameter & Description & LB & UB & Default \\
\hline POT_FR & Fraction of HRU area that drains into pothole & 0 & 1 & 0 \\
\hline POT_TILE & $\begin{array}{l}\text { Average daily outflow to main channel from tile flow if drainage tiles } \\
\text { are installed in the pothole }\end{array}$ & 0 & 100 & 0 \\
\hline POT_VOLX & Maximum volume of water stored in the pothole & 0 & 100 & 0 \\
\hline POT_VOL & Initial volume of water stored in the pothole & 0 & 100 & 0 \\
\hline SED_CON & Sediment concentration in runoff, after urban BMP is applied & 0 & 5000 & 0 \\
\hline ORGN_CON & Organic nitrogen concentration in runoff, after urban BMP is applied & 0 & 100 & 0 \\
\hline ORGP_CON & Organic phosphorus concentration in runoff, after urban BMP is applied & 0 & 50 & 0 \\
\hline SOLN_CON & Soluble nitrogen concentration in runoff, after urban BMP is applied & 0 & 10 & 0 \\
\hline SOLP_CON & Soluble phosphorus concentration in runoff, after urban BMP is applied & 0 & 3 & 0 \\
\hline
\end{tabular}

\section{Appendix C}

Table C1. Printable SWAT variables for reach outputs.

\begin{tabular}{|c|c|}
\hline \multicolumn{2}{|r|}{ Reach Output Variables } \\
\hline Parameter & Description \\
\hline FLOW_IN & Average daily streamflow into reach $\left(\mathrm{m}^{3} / \mathrm{s}\right)$ \\
\hline FLOW_OUT & Average daily streamflow out of reach $\left(\mathrm{m}^{3} / \mathrm{s}\right)$ \\
\hline EVAP & Average daily loss of water from reach by evaporation $\left(\mathrm{m}^{3} / \mathrm{s}\right)$ \\
\hline TLOSS & Average daily loss of water from reach by transmission $\left(\mathrm{m}^{3} / \mathrm{s}\right)$ \\
\hline SED_IN & Sediment transported with water into reach (metric tons) \\
\hline SED_OUT & Sediment transported with water out of reach (metric tons) \\
\hline SEDCONC & Concentration of sediment in reach $(\mathrm{mg} / \mathrm{L})$ \\
\hline ORGN_IN & Organic nitrogen transported with water into reach $(\mathrm{kg} \cdot \mathrm{N})$ \\
\hline ORGN_OUT & Organic nitrogen transported with water out of reach $(\mathrm{kg} \cdot \mathrm{N})$ \\
\hline ORGP_IN & Organic phosphorus transported with water into reach $(\mathrm{kg} \cdot \mathrm{P})$ \\
\hline ORGP_OUT & Organic phosphorus transported with water out of reach $(\mathrm{kg} \cdot \mathrm{P})$ \\
\hline NO3_IN & Nitrate transported with water into reach $(\mathrm{kg} \cdot \mathrm{N})$ \\
\hline NO3_OUT & Nitrate transported with water out of reach $(\mathrm{kg} \cdot \mathrm{N})$ \\
\hline NH4_IN & Ammonium transported with water into reach $(\mathrm{kg} \cdot \mathrm{N})$ \\
\hline NH4_OUT & Ammonium transported with water out of reach $(\mathrm{kg} \cdot \mathrm{N})$ \\
\hline NO2_IN & Nitrite transported with water into reach $(\mathrm{kg} \cdot \mathrm{N})$ \\
\hline NO2_OUT & Nitrite transported with water out of reach $(\mathrm{kg} \cdot \mathrm{N})$ \\
\hline MINP_IN & Mineral phosphorus transported with water into reach $(\mathrm{kg} \cdot \mathrm{P})$ \\
\hline MINP_OUT & Mineral phosphorus transported with water out of reach $(\mathrm{kg} \cdot \mathrm{P})$ \\
\hline CHLA_IN & Chlorophyll-a transported with water into reach $(\mathrm{kg})$ \\
\hline CHLA_ŌUT & Chlorophyll-a transported with water out of reach $(\mathrm{kg})$ \\
\hline CBOD_IN & Carbonaceous biochemical oxygen demand transported into reach $\left(\mathrm{kg} \cdot \mathrm{O}_{2}\right)$ \\
\hline CBOD_OUT & Carbonaceous biochemical oxygen demand transported out of reach $\left(\mathrm{kg} \cdot \mathrm{O}_{2}\right)$ \\
\hline DISOX̄_IN & Dissolved oxygen transported into reach $\left(\mathrm{kg} \cdot \mathrm{O}_{2}\right)$ \\
\hline DISOX_OUT & Dissolved oxygen transported out of reach $\left(\mathrm{kg} \cdot \mathrm{O}_{2}\right)$ \\
\hline SOLPST_IN & Soluble pesticide transported with water into reach (mg a.i.) \\
\hline SOLPST_OUT & Soluble pesticide transported with water out of reach (mg a.i.) \\
\hline SORPST_IN & Pesticide sorbed to sediment transported with water into reach (mg a.i.) \\
\hline SORPST_OUT & Pesticide sorbed to sediment transported with water out of reach (mg a.i.) \\
\hline REACTPST & Loss of pesticide from water by reaction (mg a.i.) \\
\hline
\end{tabular}


Table C1. Cont.

\begin{tabular}{cl}
\hline & \multicolumn{1}{c}{ Reach Output Variables } \\
\hline Parameter & \multicolumn{1}{c}{ Description } \\
\hline VOLPST & Loss of pesticide from water by volatilization $(\mathrm{mg}$ a.i.) \\
SETTLPST & Transfer of pesticide from water to river bed sediment by settling (mg a.i.) \\
RESUSP_PST & Transfer of pesticide from river bed sediment to water by resuspension (mg a.i.) \\
DIFFUSEPST & Transfer of pesticide from water to river bed sediment by diffusion (mg a.i.) \\
REACBEDPST & Loss of pesticide from river bed sediment by reaction $(\mathrm{mg}$ a.i.) \\
BURYPST & Loss of pesticide from river bed sediment by burial $(\mathrm{mg}$ a.i.) \\
BED_PST & Pesticide in river bed sediment $(\mathrm{mg}$ a.i.) \\
BACTP_OUT & Number of persistent bacteria transported out of reach (\# cfu/100 mL) \\
BACTLP_OUT & Number of less persistent bacteria transported out of reach (\# cfu/100 $\mathrm{mL})$ \\
CMETAL\#1 & Conservative metal \#1 transported out of reach $(\mathrm{kg})$ \\
CMETAL\#2 & Conservative metal \#2 transported out of reach $(\mathrm{kg})$ \\
CMETAL\#3 & Conservative metal \#3 transported out of reach $(\mathrm{kg})$ \\
TOT_N & Total Nitrogen $(\mathrm{kg})$ \\
TOT_P & Total Phosphorus $(\mathrm{kg})$ \\
NO3CONC & Nitrate Concentration $(\mathrm{mg} / \mathrm{L})$ \\
\hline
\end{tabular}

Table C2. Printable SWAT variables for subbasin outputs.

\begin{tabular}{cl}
\hline & \multicolumn{1}{c}{ Subbasin Output Variables } \\
\hline Parameter & \multicolumn{1}{c}{ Description } \\
\hline PRECIP & Average total precipitation on subbasin $\left(\mathrm{mm} \cdot \mathrm{H}_{2} \mathrm{O}\right)$ \\
SNOMELT & Snow melt $\left(\mathrm{mm} \cdot \mathrm{H}_{2} \mathrm{O}\right)$ \\
PET & Potential evapotranspiration $\left(\mathrm{mm} \cdot \mathrm{H}_{2} \mathrm{O}\right)$ \\
ET & Actual evapotranspiration $\left(\mathrm{mm} \cdot \mathrm{H}_{2} \mathrm{O}\right)$ \\
SW & Soil water content $\left(\mathrm{mm} \cdot \mathrm{H}_{2} \mathrm{O}\right)$ \\
PERC & Amount of water percolating out of root zone $\left(\mathrm{mm} \cdot \mathrm{H}_{2} \mathrm{O}\right)$ \\
SURQ & Surface runoff $\left(\mathrm{mm} \cdot \mathrm{H}_{2} \mathrm{O}\right)$ \\
GW_Q & Groundwater discharge into reach $\left(\mathrm{mm} \cdot \mathrm{H}_{2} \mathrm{O}\right)$ \\
WYLD & Net water yield to reach $\left(\mathrm{mm} \cdot \mathrm{H}_{2} \mathrm{O}\right)$ \\
SYLD & Sediment yield (metric tons $/ \mathrm{ha})$ \\
ORGN & Organic N released into reach $(\mathrm{kg} / \mathrm{ha})$ \\
ORGP & Organic P released into reach $(\mathrm{kg} / \mathrm{ha})$ \\
NSURQ & Nitrate released into reach $(\mathrm{kg} / \mathrm{ha})$ \\
SOLP & Soluble P released into reach $(\mathrm{kg} / \mathrm{ha})$ \\
SEDP & Mineral P attached to sediment released into reach $(\mathrm{kg} / \mathrm{ha})$ \\
\hline
\end{tabular}

Table C3. Printable SWAT variables for HRU outputs.

\begin{tabular}{cl}
\hline & \multicolumn{1}{c}{ HRU Output Variables } \\
\hline Parameter & \multicolumn{1}{c}{ Description } \\
\hline PRECIP & Total precipitation on HRU $\left(\mathrm{mm} \cdot \mathrm{H}_{2} \mathrm{O}\right)$ \\
SNOFALL & Precipitation falling as snow, sleet, or freezing rain $\left(\mathrm{mm} \cdot \mathrm{H}_{2} \mathrm{O}\right)$ \\
SNOMELT & Amount of snow or ice melting $\left(\mathrm{mm} \cdot \mathrm{H}_{2} \mathrm{O}\right)$ \\
IRR & Amount of irrigation water applied to HRU $\left(\mathrm{mm} \cdot \mathrm{H}_{2} \mathrm{O}\right)$ \\
PET & Potential evapotranspiration $\left(\mathrm{mm} \cdot \mathrm{H}_{2} \mathrm{O}\right)$ \\
ET & Amount of water removed by evapotranspiration $\left(\mathrm{mm} \cdot \mathrm{H}_{2} \mathrm{O}\right)$ \\
SW_INIT & Soil water content at beginning of time period $\left(\mathrm{mm} \cdot \mathrm{H}_{2} \mathrm{O}\right)$ \\
SW_END & Soil water content at end of time period (mm $\left.\cdot \mathrm{H}_{2} \mathrm{O}\right)$ \\
PERC & Amount of water percolating out of the root zone $\left(\mathrm{mm} \cdot \mathrm{H}_{2} \mathrm{O}\right)$ \\
GW_RCHG & Amount of water entering both aquifers (mm $\left.\cdot \mathrm{H}_{2} \mathrm{O}\right)$ \\
DA_RCHG & Amount of water entering deep aquifer from root zone $\left(\mathrm{mm} \cdot \mathrm{H}_{2} \mathrm{O}\right)$ \\
REVAP & Water in shallow aquifer returning to root zone $\left(\mathrm{mm} \cdot \mathrm{H}_{2} \mathrm{O}\right)$ \\
SA_IRR & Amount of water removed from shallow aquifer for irrigation $\left(\mathrm{mm} \cdot \mathrm{H}_{2} \mathrm{O}\right)$ \\
DA_IRR & Amount of water removed from deep aquifer for irrigation $\left(\mathrm{mm} \cdot \mathrm{H}_{2} \mathrm{O}\right)$ \\
SA_ST & Amount of water in shallow aquifer storage at end of time period $\left(\mathrm{mm} \cdot \mathrm{H}_{2} \mathrm{O}\right)$ \\
\hline
\end{tabular}


Table C3. Cont.

\begin{tabular}{|c|c|}
\hline \multicolumn{2}{|r|}{ HRU Output Variables } \\
\hline Parameter & Description \\
\hline DA_ST & Amount of water in deep aquifer storage at end of time period $\left(\mathrm{mm} \cdot \mathrm{H}_{2} \mathrm{O}\right)$ \\
\hline SURQ_GEN & Surface runoff generated during time step $\left(\mathrm{mm} \cdot \mathrm{H}_{2} \mathrm{O}\right)$ \\
\hline SURQ_CNT & Surface runoff contribution to reach $\left(\mathrm{mm} \cdot \mathrm{H}_{2} \mathrm{O}\right)$ \\
\hline TLOSS & Amount of water removed from tributary channels by transmission $\left(\mathrm{mm} \cdot \mathrm{H}_{2} \mathrm{O}\right)$ \\
\hline LATQ & Lateral flow contribution to reach $\left(\mathrm{mm} \cdot \mathrm{H}_{2} \mathrm{O}\right)$ \\
\hline GW_Q & Groundwater discharge into reach $\left(\mathrm{mm} \cdot \mathrm{H}_{2} \mathrm{O}\right)$ \\
\hline WYL̄D & Net amount of water contributed by the HRU to the reach $\left(\mathrm{mm} \cdot \mathrm{H}_{2} \mathrm{O}\right)$ \\
\hline DAILYCN & Average curve number for time period \\
\hline TMP_AV & Average air temperature for time period $\left({ }^{\circ} \mathrm{C}\right)$ \\
\hline TMP_MX & Average of daily maximum air temperatures for time period $\left({ }^{\circ} \mathrm{C}\right)$. \\
\hline TMP_MN & Average of daily minimum air temperatures for time period $\left({ }^{\circ} \mathrm{C}\right)$. \\
\hline SOL_TMP & Average soil temperature in time period $\left({ }^{\circ} \mathrm{C}\right)$ \\
\hline SOLAR & Average daily solar radiation for time period $\left(\mathrm{MJ} / \mathrm{m}^{2}\right)$ \\
\hline SYLD & Amount of sediment contributed by the HRU to the reach (metric tons/ha) \\
\hline USLE & USLE soil loss (metric tons/ha) \\
\hline N_APP & Amount of $\mathrm{N}$ fertilizer applied in regular fertilizer operation $(\mathrm{kg} \cdot \mathrm{N} / \mathrm{ha})$ \\
\hline P_APP & Amount of $\mathrm{P}$ fertilizer applied in regular fertilizer operation $(\mathrm{kg} \cdot \mathrm{P} / \mathrm{ha})$ \\
\hline NĀUTO & Amount of $\mathrm{N}$ fertilizer applied automatically $(\mathrm{kg} \cdot \mathrm{N} / \mathrm{ha})$ \\
\hline PAUTO & Amount of $\mathrm{P}$ fertilizer applied automatically $(\mathrm{kg} \cdot \mathrm{P} / \mathrm{ha})$ \\
\hline NGRZ & Nitrogen applied to HRU in grazing operation during time step $(\mathrm{kg} \cdot \mathrm{N} / \mathrm{ha})$ \\
\hline PGRZ & Phosphorus applied to HRU in grazing operation during time step $(\mathrm{kg} \cdot \mathrm{P} / \mathrm{ha})$ \\
\hline CFERTN & Nitrogen applied to HRU in continuous fertilizer operation during time step $(\mathrm{kg} \cdot \mathrm{N} / \mathrm{ha})$ \\
\hline CFERTP & Phosphorus applied to HRU in continuous fertilizer operation during time step $(\mathrm{kg} \cdot \mathrm{P} / \mathrm{ha})$ \\
\hline NRAIN & Nitrate added in rainfall $(\mathrm{kg} \cdot \mathrm{N} / \mathrm{ha})$ \\
\hline NFIX & Amount of $\mathrm{N}$ fixed by legumes $(\mathrm{kg} \cdot \mathrm{N} / \mathrm{ha})$ \\
\hline F-MN & Transformation of $\mathrm{N}$ from fresh organic to mineral pool $(\mathrm{kg} \cdot \mathrm{N} / \mathrm{ha})$ \\
\hline A-MN & Transformation of $\mathrm{N}$ from active organic to mineral pool $(\mathrm{kg} \cdot \mathrm{N} / \mathrm{ha})$ \\
\hline A-SN & Transformation of $\mathrm{N}$ from active organic to stable organic pool $(\mathrm{kg} \cdot \mathrm{N} / \mathrm{ha})$ \\
\hline F-MP & Transformation of $\mathrm{P}$ from fresh organic to mineral (solution) pool (kg. $\mathrm{P} / \mathrm{ha}$ ) \\
\hline AO-LP & Transformation of $\mathrm{P}$ from organic to labile pool $(\mathrm{kg} \cdot \mathrm{P} / \mathrm{ha})$ \\
\hline L-AP & Transformation of $\mathrm{P}$ from labile to active mineral pool $(\mathrm{kg} \cdot \mathrm{P} / \mathrm{ha})$ \\
\hline A-SP & Transformation of $\mathrm{P}$ from active mineral to stable mineral pool $(\mathrm{kg} \cdot \mathrm{P} / \mathrm{ha})$ \\
\hline DNIT & Amount of $\mathrm{N}$ removed from soil by denitrification $(\mathrm{kg} \cdot \mathrm{N} / \mathrm{ha})$ \\
\hline NUP & Nitrogen uptake by plants $(\mathrm{kg} \cdot \mathrm{N} / \mathrm{ha})$ \\
\hline PUP & Phosphorus uptake by plants (kg. P/ha) \\
\hline ORGN & Organic $\mathrm{N}$ contributed by HRU to reach $(\mathrm{kg} \cdot \mathrm{N} / \mathrm{ha})$ \\
\hline ORGP & Organic $\mathrm{P}$ contributed by HRU to reach $(\mathrm{kg} \cdot \mathrm{P} / \mathrm{ha})$ \\
\hline SEDP & Mineral $\mathrm{P}$ attached to sediment contributed by HRU to reach $(\mathrm{kg} \cdot \mathrm{P} / \mathrm{ha})$ \\
\hline NSURQ & NO3 contributed by HRU in surface runoff to reach $(\mathrm{kg} \cdot \mathrm{N} / \mathrm{ha})$ \\
\hline NLATQ & NO3 contributed by HRU in lateral flow to reach $(\mathrm{kg} \cdot \mathrm{N} / \mathrm{ha})$ \\
\hline NO3L & NO3 leached below the soil profile $(\mathrm{kg} \cdot \mathrm{N} / \mathrm{ha})$ \\
\hline NO3GW & $\mathrm{NO} 3$ contributed by HRU in groundwater flow to reach $(\mathrm{kg} \cdot \mathrm{N} / \mathrm{ha})$ \\
\hline SOLP & Soluble phosphorus contributed by HRU in surface runoff to reach $(\mathrm{kg} \cdot \mathrm{P} / \mathrm{ha})$ \\
\hline P_GW & Soluble phosphorus contributed by HRU in groundwater flow to reach $(\mathrm{kg} \cdot \mathrm{P} / \mathrm{ha})$ \\
\hline W_STRS & Number of water stress days \\
\hline TMP_STRS & Number of temperature stress days \\
\hline N_STRS & Number of nitrogen stress days \\
\hline P_STRS & Number of phosphorus stress days \\
\hline BIOM & Total plant biomass (metric tons $/ \mathrm{ha}$ ) \\
\hline LAI & Leaf area index \\
\hline YLD & Harvested yield (metric $\cdot$ tons $/$ ha) \\
\hline BACTP & Persistent bacteria in surface runoff $\left(\# \mathrm{cfu} / \mathrm{m}^{2}\right)$ \\
\hline BACTLP & Number of less persistent bacteria in surface runoff $\left(\# \mathrm{cfu} / \mathrm{m}^{2}\right)$ \\
\hline
\end{tabular}

\section{References}

1. Jha, M.K.; Gassman, P.W. Changes in hydrology and streamflow as predicted by a modelling experiment forced with climate models. Hydrol. Process. 2014, 28, 2772-2781. [CrossRef]

2. White, M.J.; Gambone, M.; Yen, H.; Arnold, J.G.; Harmel, R.D.; Santhi, C.; Haney, R. Regional Blue and Green Water Balances and Use by Selected Crops in the U.S. J. Am. Water Resour. Assoc. 2015, 51. [CrossRef]

3. Bai, Y.; Wagener, T.; Reed, P. A top-down framework for watershed model evaluation and selection under uncertainty. Environ. Model. Softw. 2009, 24, 901-916. [CrossRef] 
4. Chou, F.N.-F.; Wu, C.-W. Determination of cost coefficients of a priority-based water allocation linear programming model-A network flow approach. Hydrol. Earth Syst. Sci. 2014, 18, 1857-1872. [CrossRef]

5. Winsemius, H.C.; Schaefli, B.; Montanari, A.; Savenije, H.H.G. On the calibration of hydrological models in ungauged basins: A framework for integrating hard and soft hydrological information. Water Resour. Res. 2009, 45, 1-15. [CrossRef]

6. Williams, J.W.; Izaurralde, R.C.; Steglich, E.M. Agricultural Policy/Environmental EXtender Model Theoretical Documentation Version 0806; Texas A\&M University: College Station, TX, 2012; p. 131.

7. Bicknell, B.R.; Imhoff, J.C.; Kittle, J.L., Jr.; Donigian, A.S.; Johanson, R.C. Hydrological Simulation Program-Fortran: User's manual for version 11; U.S. Environmental Protection Agency, National Exposure Research Laboratory: Athens, GA, USA, 1997; p. 755.

8. Arnold, J.G.; Moriasi, D.; Gassman, P.; Abbaspour, K.C.; White, M.J.; Srinivasan, R.; Santhi, C.; Harmel, R.D.; van Griensven, A.; Van Liew, M.W.; Kannan, N.; et al. SWAT: Model use, calibration, and validation. Trans. ASABE 2012, 55, 1491-1508. [CrossRef]

9. Arnold, J.G.; Youssef, M.; Yen, H.; White, M.; Sheshukov, A.; Sadeghi, A.; Moriasi, D.; Steiner, J.; Amatya, D.; Haney, E.; et al. Hydrological Processes and Model Representation. Trans. ASABE 2015, 58, 1637-1660.

10. Iowa State University, Center for Agricultural and Rural Development, SWAT Literature Database for Peer-Reviewed Journal Articles. Available online: https://www.card.iastate.edu/swat_articles/ (accessed on 19 February 2016).

11. Neitsch, S.L.; Arnold, J.G.; Kiniry, J.R.; Williams, J.R. Soil and Water Assessment Tool Theoretical Documentation Version 2009; Texas Water Resources Institute: College Station, TX, USA, 2011.

12. Moriasi, D.N.; Arnold, J.G.; Liew, M.W.V.; Bingner, R.L.; Harmel, R.D.; Veith, T.L. Model Evaluation Guidelines for Systematic Quantification of Accuracy in Watershed Simulations. Trans. ASABE 2007, 50, 885-900. [CrossRef]

13. Moriasi, D.N.; Gitau, G.W.; Pai, N.; Daggupati, P. Hydrologic and water quality models: Performance measures and criteria. Trans. ASABE 2015, 58, 1763-1785.

14. Yen, H.; Wang, X.; Fontane, D.G.; Arabi, M.; Harmel, R.D. A framework for propagation of uncertainty contributed by input data, parameterization, model structure, and calibration/validation data in watershed modeling. Environ. Model. Softw. 2014, 54. [CrossRef]

15. Abbaspour, K.C.; Yang, J.; Maximov, I.; Siber, R.; Bogner, K.; Mieleitner, J.; Zobrist, J.; Srinivasa, R. Modelling hydrology and water quality in the pre-alpine/alpine Thur watershed using SWAT. J. Hydrol. 2007, 333, 413-430. [CrossRef]

16. Yen, H.; Jeong, J.; Tseng, W-H.; Kim, M-K.; Records, R.M.; Arabi, M. Computational procedure for evaluating sampling techniques on watershed model calibration. J. Hydrol. Eng. 2015, 20. [CrossRef]

17. De, S.; Bezuglov, A. Data model for a decision support in comprehensive nutrient management in the United States. Environ. Modell. Softw. 2006, 21, 852-867. [CrossRef]

18. Miller, S.N.; Semmens, D.J.; Goodrich, D.C.; Hernandez, M.; Miller, R.C.; Kepner, W.G.; Guertin, D.P. The automated geospatial watershed assessment tool. Environ. Modell. Softw. 2007, 22, 365-377. [CrossRef]

19. Texas A\&M University. Hydrologic and Water Quality System. Availalble online: https://epahawqs.tamu.edu/ (accessed on 19 February 2016).

20. Arnold, J.G.; Allen, P.M.; Bernhardt, G. A comprehensive surfacegroundwater flow model. J. Hydrol. 1993, 142, 47-69. [CrossRef]

21. Gassman, P.W.; Reyes, M.R.; Green, C.H.; Arnold, J.G. The soil and water assessment tool: Historical development, applications and future research directions. Trans. Am. Soc. Agric. Biol. Eng. 2007, 50, 1211-1250. [CrossRef]

22. Daggupati, P.; Yen, H.; White, M.J.; Srinivasan, R.; Arnold, J.G.; Keitzer, C.S.; Sowa, S.P. Impact of model development, calibration and validation decisions on hydrological simulations in West Lake Erie Basin. Hydrol. Process. 2015, 29, 5307-5320. [CrossRef]

23. Texas A\&M University. Soil and Water Assessment Tool. ArcSWAT Interface and documentations. Available online: http:/ / swat.tamu.edu/software/arcswat/ (accessed on 19 February 2016).

24. University of Illinois at Urbana-Champaign. Atmosphere Deposition-National Atmospheric Deposition Program (NADP). Available online: http:/ /nadp.sws.uiuc.edu/ (accessed on 19 February 2016). 
25. United States Department of Agriculture, Natural Resources Conservation Practices, Climate-Parameter-elevation Regressions on Independent Slopes Model (PRISM). Available online: http:/ / www.wcc.nrcs.usda.gov/climate/prism.html (accessed on 19 February 2016).

26. United States Geological Survey, Land Use (non-agricultural)-National Land Cover Database (NLCD). Available online: http://www.mrlc.gov/nlcd06_data.php (accessed on 19 February 2016).

27. United States Department of Agriculture; National Agricultural Statistics Service (NASS). Land Use-Cropland Data Layer (Agricultural). Available online: http://nassgeodata.gmu.edu/CropScape/ (accessed on 19 February 2016).

28. United States Corps pf Engineers, Reservoirs-National Inventory of Dams (NID). Available online: http:/ / nid.usace.army.mil/cm_apex/f?p=838:5:0::NO (accessed on 19 February 2016).

29. United States Geological Survey, River Discharge Data. Available online: http://waterdata.usgs.gov/nwis (accessed on 19 February 2016).

30. United States Department of Agriculture, Natural Resources Conservation Practices, State Soil Geographic Data. Available online: http://sdmdataaccess.nrcs.usda.gov/ (accessed on 19 February 2016).

31. United States Geological Survey, Global Data Explorer. Available online: http://gdex.cr.usgs.gov/gdex/ (accessed on 19 February 2016).

32. United States Geological Survey, Water Usage Data. Available online: http://water.usgs.gov/watuse/data/ (accessed on 19 February 2016).

33. Michael, W.; Harmel, J.; Daren, R.; Arnold, J.G.; Williams, J.R. SWAT Check: A screening tool to assist users in the identification of potential model application problems. J. Environ. Qual. 2014, 43, 208-214.

34. United State Environmental Protection Agency (USEPA). Environmental Impact and Benefits Assessment for Final Effluent Guidelines and Standards for the Construction and Development Category; Office of Water: Washington, DC, USA, 2009.

35. Illinois Environmental Protection Agency. Water Quality for Citizens. Available online: http://www.epa. illinois.gov/ (accessed on 19 February 2016).

36. Daggupati, P.; Pai, N.; Ale, S.; Douglas-Mankin, K.R.; Zeckoski, R.W.; Jeong, J.; Parajuli, P.B.; Saraswat, D.; Youssef, M.A. A recommended calibration and validation strategy for hydrologic and water quality models. Trans. ASABE 2015, 58, 1705-1719.

37. Nash, J.E.; Sutcliffe, J.V. River flow forecasting through conceptual models part I-A discussion of principles. J. Hydrol. 1970, 10, 282-290. [CrossRef]

38. Dungjen, T.; Patch, D. Toledo-area Water Advisory Expected to Continue through Sunday as Leaders Await Tests. The Blade. Available online: http://www.toledoblade.com/local/2014/08/02/ City-of-Toledo-issues-do-no-drink-water-advisery.html (accessed on 19 February 2016). 